\title{
具有芳并咪唑结构单元的叶绿素类二氢卟吩衍生物的合成
}

\author{
张 珠 ${ }^{a}$ 赵 雨 ${ }^{b}$ 王欣悦 ${ }^{b}$ 李家柱 ${ }^{b}$ 王进军*,a,b

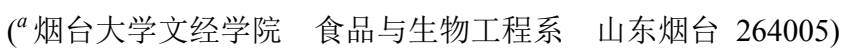 \\ ( ${ }^{b}$ 烟台大学化学化工学院 烟台 264005)
}

\begin{abstract}
摘要 以脱镁叶绿酸-a 甲酯为起始原料, 利用其外接环的结构转换, 在 $\mathrm{N}^{21}-\mathrm{N}^{23}$ 轴水溶性端向的不同位置上构建了甲酰 基和邻位二酮结构; 通过连有活性官能团的叶绿素类二氢卟吩与多种芳香邻位二胺进行类 Phillps-Ladenburg 反应，以 连接和并合的方式在其周环上引进了芳并咪唑结构单元; 完成了一系列未见报道的具有芳并咪唑结构单元的叶绿素类 二氢卟吩衍生物的合成, 讨论了相应的反应机理和咪唑化产物的紫外-可见光谱性质. 所有新合成化合物的结构均经 UV-Vis、IR、 ${ }^{1} H$ NMR、MS 及元素分析予以证实.
\end{abstract}

关键词 叶绿素; 脱镁叶绿酸; 二氢卟吩; 芳并咪夾化; 合成

\section{Syntheses of Chlorophyllous Chlorin Derivatives with Aromatic Ring-Fused Imidazole Structural Unit}

\author{
Zhang, Zhu ${ }^{a} \quad{\text { Zhao, } \mathrm{Yu}^{a} \quad \text { Wang, Xinyue }^{b} \quad \mathrm{Li} \text {, Jiazhu }}^{b} \quad$ Wang, Jinjun ${ }^{*, a, b}$ \\ ( ${ }^{a}$ Department of Food \& Biological Engineering, Wenjing College, Yantai University, Yantai, Shandong 264005) \\ $\left({ }^{b}\right.$ College of Chemistry and Chemical Engineering, Yantai University, Yantai, Shandong 264005)
}

\begin{abstract}
Using pheophorbide-a methyl ester as starting material, the formyl group and $\alpha$-diketone moiety were introduced into the water-soluble end of $\mathrm{N}^{21}-\mathrm{N}^{23}$ axis at different positions by the structural transformation on exocyclic ring. Furthermore, using the Phillps-Ladenburg-like reaction of active functional groups in chlorophyll chlorins with various aromatic $o$-diamines, the aromatic ring-fused imidazole structural units were created in linkage or fused manner, and a series of unreported chlorin derivatives that contain aryl-fused imidazol unit were finally synthesized. Besides, the relevant reaction mechanism was analyzed, and the absorption properties of these imidazolized products were discussed. The chemical structures of all newly synthesized compounds were characterized by elemental analysis, MS, UV-Vis, IR and ${ }^{1} \mathrm{H}$ NMR spectra.
\end{abstract}

Keywords chlorophyll; pheophorbide; chlorin; aromatic ring-fused imidazolization; synthesis

\section{Introduction}

The chlorins degradated from the naturally occurring chlorophyll are aromatic macrocyclic compounds, which consist of three $\beta$-substituted pyrroles and one pyrroline connected at $\alpha$-positions by four bridging methine carbons. These chlorophyll derivatives are very different from the common porphyrins in many aspects owing to their asymmetric structures and multiple reaction sites. In recent years, the heteroaromatic ring-fused or attached porphyrins have received much attention because of their unique optical and electrochemical properties, such as the intense near-infrared (NIR) absorption, narrowed HOMO-LUMO gaps and the high tendency of forming intermolecular $\pi-\pi$ stacking structure. ${ }^{[1]}$ Such porphyrins have been synthesized by fusion or connection with various aromatic rings, and are widely used as dyes in the area of photodynamic therapy, NIR photodetectors, photovoltaics, semiconductors and two-photon absorbing materials. ${ }^{[2]}$ Incorporation of the rigid aromatic system may cause the distortion of the tetrapyrrole macrocycle plane, leading to unique photophysical characteristics of these compounds, while the linearly linked aromatic ring can change the symmetry of molecular structure. The substituent effect impacted on porphyrinic $\pi$-system has been considered as one main reason of their unique photophysical characteristics. ${ }^{[3]}$ Therefore, the introduction of heteroaromatic group into the porphyrin periphery has become an important synthetic

* Corresponding author. E-mail: wjj1955@163.com

Received June 30, 2020; revised October 19, 2020; published online November 3, 2020.

Project supported by the National Natural Science Foundations of China (No. 21272048) and the Natural Science Foundation of Shandong Province (No. ZR2015BQ012).

国家自然科学基金(No. 21272048)和山东省自然科学基金(No. ZR2015BQ012)资助项目. 
strategy for acquiring homologous compounds with potential applications.

However, it is difficult to construct the aromatic ringfused or attached naturally occurring chlorophyll architectures due to the complicated substituents around the macrocycle periphery. In general, the related reports are still very limited except the early works ${ }^{[4]}$ of our group and some other groups. ${ }^{[5]}$ In these studies, various heteroaromatic rings were introduced in the chlorophyllous chromophore, including pyridine, pyridazine, triazine, thiophene, quinoxaline and quinoline. To further investigate the periphery functionalization of chlorins-related chlorophyll and search for effective dyes for various fields, herein, we reported the synthesis of a series of novel chlorins by introducing the aromatic-fused imidazole structural unit around $\mathrm{N}^{21}-\mathrm{N}^{23}$ axis, which may profoundly influence their optical and electrochemical properties. This work also focused on the features of these aromatic-fused imidazoles, such as the dual nature in alkalinity and acidity, tautomeric equilibrium and intermolecular hydrogen bonds. More importantly, both nitrogen atoms on the five-membered ring can be used as the external coordination sites for controlling the whole macrocyclic $\pi$-system by external stimuli, such as protonation and coordination with metals. Their substitution position and combination way may also have great influence on the fundamental properties of chlorophyllous macrocycle. ${ }^{[6-8]}$

In this work, methyl pheophorbide-a (MPa, 1), prepared from the accessible Spirulina pacifica, ${ }^{[9]}$ was used as the starting material. 1 can be converted to pyropheophorbide-a (MPPa, 2a) by decarbomethoxylation in refluxing $\mathrm{AcOH} .{ }^{[10]}$ Further structural modifications of $\mathbf{2 a}$ can create new highly reactive regions on chlorin chromophore to ensure chemo- and region-selectivity in the subsequent functionalization process. One of the standard methods for preparing aromatic-fused imidazoles is the condensation of $o$-arylenediamine with aromatic aldehyde, affording Schiff base, which is then oxidized to give the corresponding target product. Owing to the sensitivity toward rigorous oxidation environment, the reaction of chlorin aldehyde with diamine was carried out under aerobic condition using air as moderate oxidant. Treatment of 12-formyl pyropheophorbide-a (2b), prepared by allomerization reaction of $\mathbf{2 a},{ }^{[1 \mathrm{a}]}$ with equimolar amount $o$-phenylenediamine (OPD) in pyridine with catalytic amount of trifluoroacetic acid (TFA) in dark at $50{ }^{\circ} \mathrm{C}$ afforded 12-benzimidazolyl substituted pyropheophorbide-a (3) in $65 \%$ yield. In the same condition and a relatively longer reaction time, the condensation of $\mathbf{2 b}$ with 2,3-diaminonaphthalene (DAN) also introduced a bulky aromatic fused imidazole fragment at 12-position to give 4 in comparably yield (61\%). To further incorporate a homologous heterocyclic skeleton to extend their $Q_{\mathrm{y}}$ maximum, we tried to build an active bifunctional structure on the exocyclic ring of $\mathbf{3}$ through a LiOH-promoted allomerization reaction. The newly formed chlorin 5 reacts with OPD in tetrahydrofuran (THF) using TFA as catalyst for $48 \mathrm{~h}$ to afford a mixture of two products, including the quinoxaleno[2,3-n]pheophorbide-a $6(28 \%)$ and benzimidazolo[2,1-n]purpurin-18 $13^{1}$ imino- $13^{2}$-imide 7 (38\%). Another way for prolonging the longest wavelength of chlorophyll derivatives is to establish an imide structure bridged at 13- and 15-positions. ${ }^{[11 \mathrm{~b}]}$ Thus, chlorin diketone $\mathbf{5}$ was converted to purpurin-18 $\mathrm{N}$-methoxyl imide $\mathbf{8}$ in $79 \%$ yield by consecutive reaction with hydroxylamine hydrochloride (Scheme 1).

In order to ensure the region-selectivity of incorporating benzoimidazole moiety, 13-formyl substituted chlorin $\mathbf{2 c},{ }^{[11 \mathrm{c}]}$ prepared from $\mathbf{1}$ by glycol construction and cleavage procedure on the E-ring, was chosen as the reaction precursor, which condensed with OPD in pyridine with TFA at $60{ }^{\circ} \mathrm{C}$ for $5 \mathrm{~h}$ to give the single benzimidazolopurpurin-18 9 in $61 \%$ yield. For the same reason, the reaction of purpurin-5 2d, ${ }^{[11 \mathrm{~d}]}$ obtained by the degradation of $\mathrm{MPa}$, with OPD under the same condition to generate the isomeric benzimidazolopurpurin-18 derivative $\mathbf{1 0}$ in comparable yield (58\%). Compared with the previous methods, ${ }^{[5 b, 11 \mathrm{e}]}$ this new approach is simple and efficient, and there is no need to separate the complicated products. In light of the forming process of benzimidazol-fused chlorins 6 and 7, C12-naphthoimidazolyl-substituted homologs 11 and 12 were synthesized in satisfactory yields by a more convenient one-pot method that integrates the LiOH-promoted allomerization with benimidazolization. In addition, another bulky aromatic $o$-diamine was chosen as reaction substrate, which reacts with pyropheophorbide-a aldehyde. Unlike using other $o$-aryldiamine, condensation of 12-formyl pyropheophorbide-a $\mathbf{2 b}$ with 3,4-diaminobenzophenone (DABP) afforded Schiff base mixture of $\mathbf{1 3 a} \sim \mathbf{1 3 b}$ as a pair of inseparable positional isomers in $27 \%$ yield, apart from the desired benzimidazol attached chlorins $14 \mathbf{a} \sim \mathbf{1 4 b}$ as a pair of tautomers with a satisfactory yield (43\%). This reaction was performed under the exact same reaction condition as that for preparing chlorin $\mathbf{3}$, and the obtained intermediate Schiff bases were found to be extremely sensitive to oxidation. If $\mathbf{1 3 a} \sim \mathbf{1 3 b}$ are stirred in pyridine with TFA at $50{ }^{\circ} \mathrm{C}$ for $5 \mathrm{~h}$ or kept at room temperature for $4 \mathrm{~d}$, these Schiff bases completely convert into 12-benzimidazol chlorins $14 a \sim 14 b$.

\section{Results and discussion}

\subsection{Aromatic ring-fused imidazolization of chlorin by Phillps-Ladenburg-like reaction}

Introduction of aryl-fused imidazol ring at different positions in the water-soluble terminal $\mathrm{N}^{21}-\mathrm{N}^{23}$ axis of chlorins with chlorophyll skeleton was accomplished by Phillps-Ladenburg-like reaction. Take the case of $\mathbf{2} \mathbf{b}$ as an example, the nucleophilic attack of aryldiamine $\mathbf{A}$ on the formyl group at 12-position in the presence TFA produces $\alpha$-hydroxyl amine $\mathbf{B}$, followed by dehydration in the manner of E2-elimination to form Schiff base 13. This unstable intermediate readily undergo an intramolecular cyclization to creat benzimidazoline framework at 12-position. The formed 12-heterocycle-substituted chlorin $\mathbf{C}$ is oxidized 

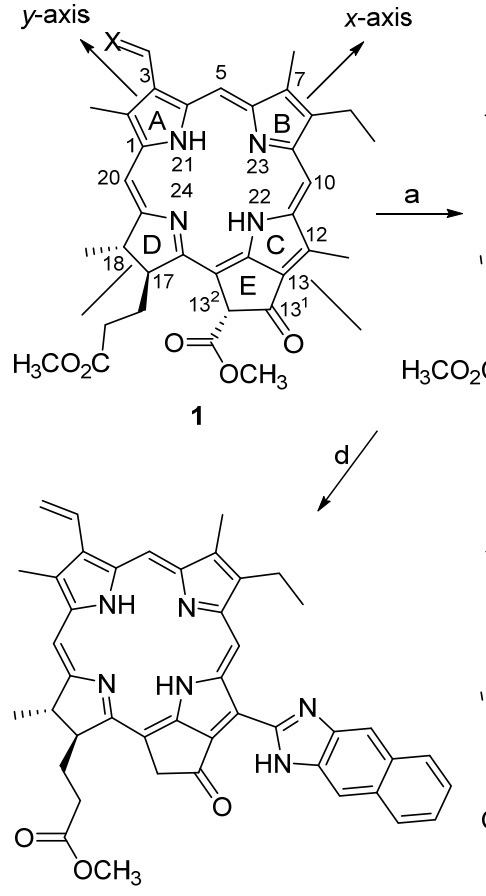

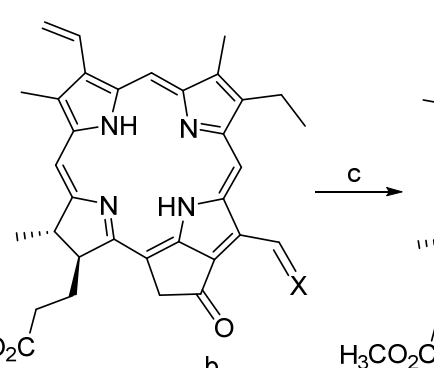

2a: $X=2 \mathrm{H} \stackrel{b}{ }$ 2a: $\mathrm{X}: \mathrm{X}=\mathrm{O}$

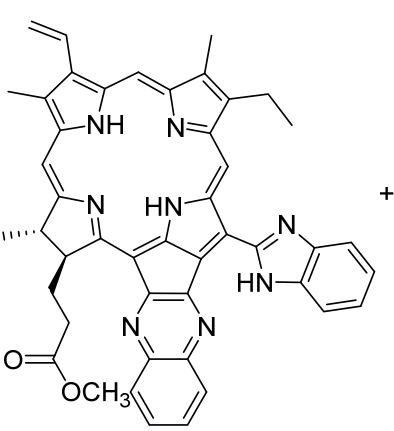

6

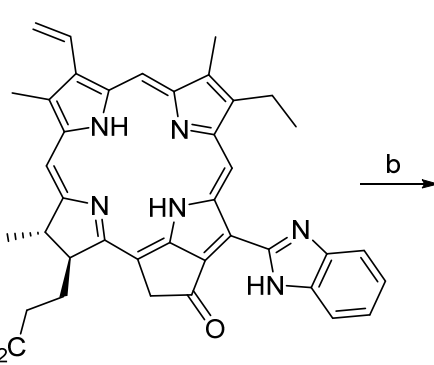

3

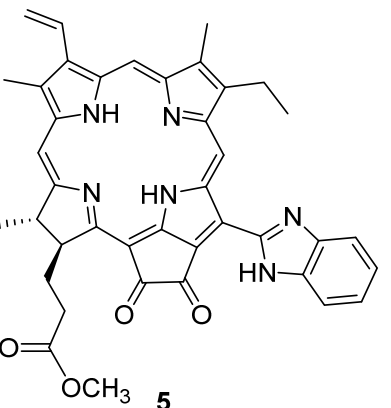

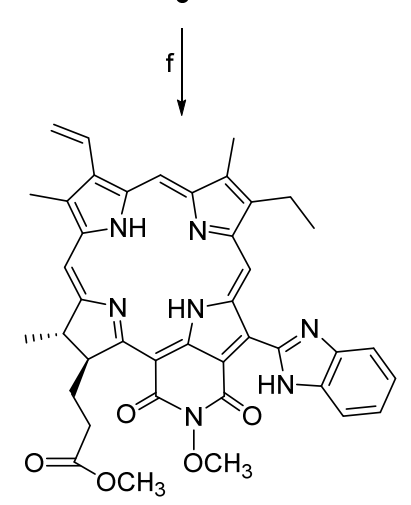

8

Reagents and conditions: (a) AcOH/reflux; (b) $\mathrm{LiOH} / \mathrm{O}_{2} / \mathrm{MeOH}$; (c) Pyr/TFA/OPD, $50{ }^{\circ} \mathrm{C}$; (d) Pyr/TFA/DAN, $50{ }^{\circ} \mathrm{C}$; (e) THF/TFA/OPD, r.t; (f) (1) pyr $/ \mathrm{MeONa} / \mathrm{MeOH} / \mathrm{O}_{2}$, (2) $\mathrm{NH}_{2} \mathrm{OH}$.

Scheme 1 Synthesis of chlorins with benzmidazole unit $\mathbf{5} \sim \mathbf{8}$ by condensation with $o$-arylenediamine (OPD) or 2,3-diaminonaphthalene (DAN)

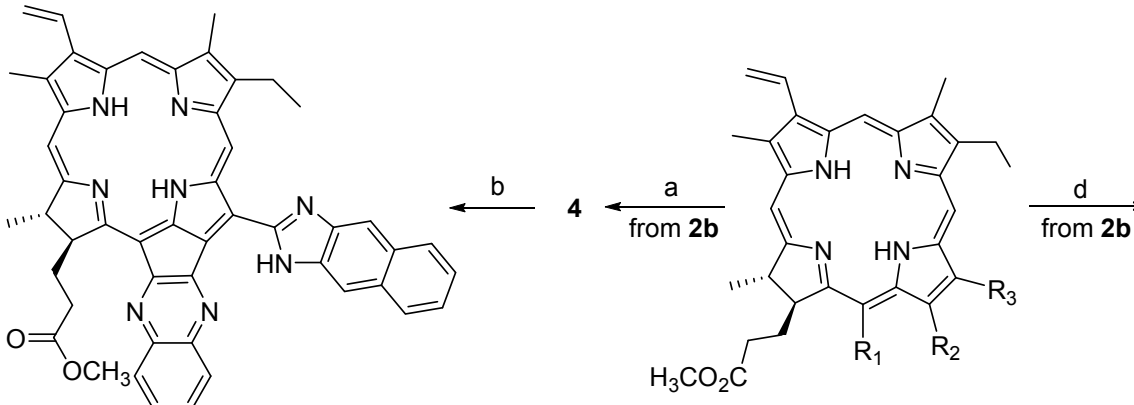

11

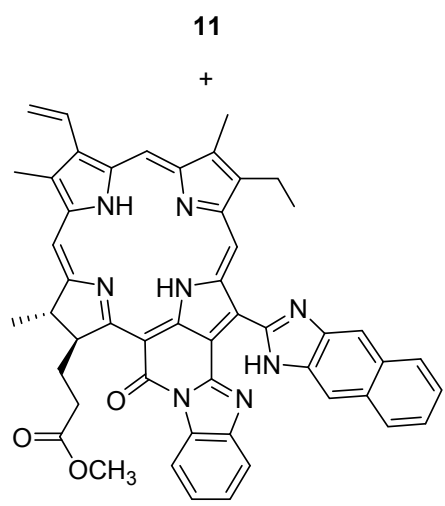

12 2b R $\mathrm{R}^{1}+\mathrm{R}^{2}=\mathrm{CH}_{2} \mathrm{CO}, \mathrm{R}^{3}=\mathrm{CHO}$;

2c $\mathrm{R}^{1}=\mathrm{CO}_{2} \mathrm{CH}_{3}, \mathrm{R}^{2}=\mathrm{CHO}, \mathrm{R}^{3}=\mathrm{CH}_{3}$

2d R $\mathrm{R}^{1}=\mathrm{CHO}, \mathrm{R}^{2}=\mathrm{CO}_{2} \mathrm{CH}_{3}, \mathrm{R}^{3}=\mathrm{CH}_{3}$;

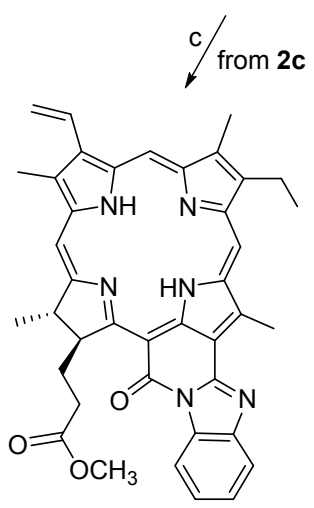

9

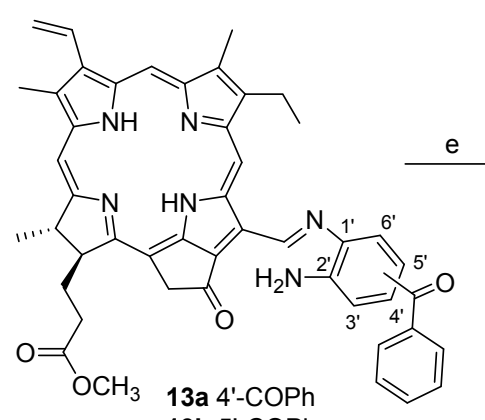

13b 5'-COPh

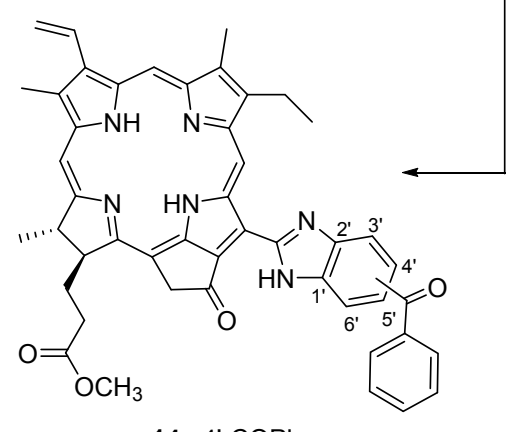

14a 4'-COPh

14b 5'-COPh

Reagents and conditions: (a) Pyr/TFA/DAN, $50{ }^{\circ} \mathrm{C}$; (b) THF/TFA/ODP, $50{ }^{\circ} \mathrm{C}$; (c) Pyr/TFA/ODP, $50{ }^{\circ} \mathrm{C}$; (d) Pyr/TFA/DABP, $50{ }^{\circ} \mathrm{C}$; (e) Pyr/TFA, $50{ }^{\circ} \mathrm{C}$

Scheme 2 Synthesis of chlorins with benzmidazole unit $\mathbf{9} \sim \mathbf{1 4}$ by condensation of $\mathbf{2}$ with $o$-arylenediamine 
into a peroxide intermediate $\mathbf{D}$ by molecular oxygen in the air, which is finally converted to chlorin $\mathbf{1 4}$ that bears the aryl-fused imidazol ring after the removal of hydrogen peroxide (Figure 1).
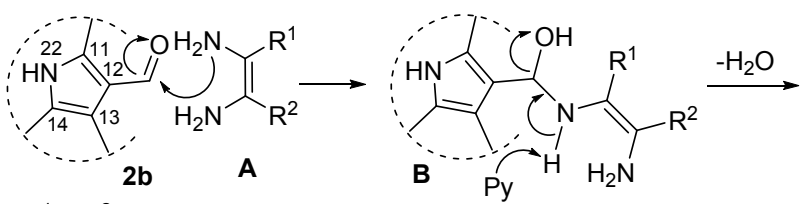

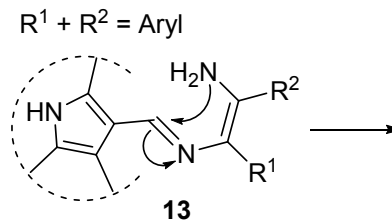

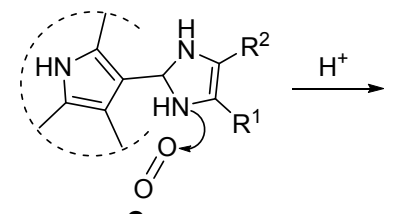

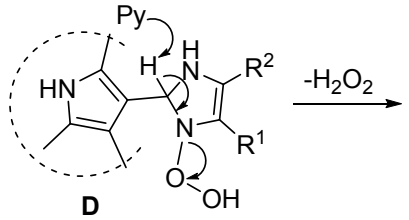
C

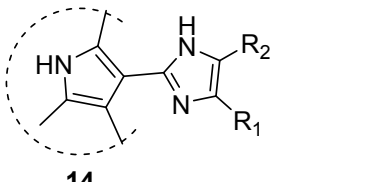
14

Figure 1 Process of aryl-fused imidazolization at 12-position

Analogously, the $\alpha$-diketone moiety in $\mathbf{2 e}$ derived from allomerization of $\mathbf{2} \mathbf{a}^{[11 \mathrm{a}]}$ should also be an active electrophilic response area due to the existence of mutual electrophilic effect between two carbonyl groups. This chlorin diketone is quite sensitive to alkali surrounding and can easily convert to cycloanhydride structure to afford purpurin-18 2f $\mathbf{f}^{[4 \mathrm{~d}]}$ in excellent yield. An attempt to synthesize benzimidazole-annulated derivatives 9 and $\mathbf{1 0}$ via a direct condensation of the oxidative product $\mathbf{2 f}$ with OPD was unsuccessful, presumably due to the poor reactivity of the conjugated anhydride ring. Thus, the formation of benzimidazolopurpurin-18 skeleton from the imidization of cyclic anhydride in $\mathbf{2 f}$ with OPD is blocked. However, the carbonyl groups of $E$-ring, such as the ketone in $\mathbf{2 a}$, the $\alpha$-diketone in $\mathbf{2 e}$ and the dicarboxylic anhydride in $\mathbf{2 f}$, could be converted to the corresponding the imine structures by the condensation with various anilines under different conditions. The synthesis of $\mathbf{2} \mathbf{h} \sim \mathbf{2} \mathbf{j}$ may be taken as an evidence for forming of $\mathrm{N}$-containing heterocyclic- fused chlorins ${ }^{[11 \mathrm{~b}-11 \mathrm{c}, 12]}$ (Figure 2).

The benimidazolization of $\mathbf{5}$ with $o$-phenylenediamine starts from the nucleophilic attack by diamine on the ketone group at $13^{1}$ - or $13^{2}$-position (roads a and b). In road $a$, this reaction first leads to the formation of the $\alpha$-hydroxyamine $\mathbf{E}$, followed by dehydration process to generate the iminoketone $\mathbf{F}$, whose another amino group in benzene ring could achieve intramolecular cyclization in two ways. The road c based on the Hinsberg reaction includes the incorporation process at $13^{2}$-position via a nucleophilic addition to afford dihydroquinoxaline $\mathbf{G}$ and subsequent dehydration reaction to complete the synthesis of quinolone-fused chlorin 6. The attack of the amino group on the $\mathrm{C} 13^{1}$-imine moiety in road-d generates the spirocyclic intermediate $\mathbf{H}$, which is then converted to chlorin peroxide I by allomerization with molecular oxygen. The following rearrangement and removal of hydrogen peroxide incorporates a benzimidaole ring to generate chlorin 7. Another reaction of 5 with OPD probably occurs at $13^{2}$-position, and the formed $\alpha$-hydroxyamine $\mathbf{J}$ comes through a series of structural transformations as the formation of chlorin 6 to give the heteroaromatic ring-fused chlorin 7', however, which was not detected in the reaction system probably due to its poor yield (Figure 3 ).

This Phillps-Ladenburg-like reaction was studied under various reaction conditions, and the reactivity of the active carbonyl groups of chlorins was found to be closely related to their positions and circumjacent space structure as well as the electronic property of adjacent substituents. The benzimidazolization of C3-formyl group with $o$-phenylenediamine was also attempted but failed, possibly due to its relatively lower reactivity. The higher reactivity of $12-$ aldehyde group in the pyropheophorbide chromophore may be mainly caused by the electronic effect of vicinal cycloketone carbonyl group. The 15- and 13-formyl groups in $\mathbf{2 c}$ and 2d, which are adjacent to an ester carbonyl group, show excellent reactivity.

\subsection{Optical properties of chlorophyllous chlorins with} aromatic ring-fused imidazole structural unit

All UV-vis spectra give three typical electronic absorption bands of chlorins with basic skeleton of chlorophyll.

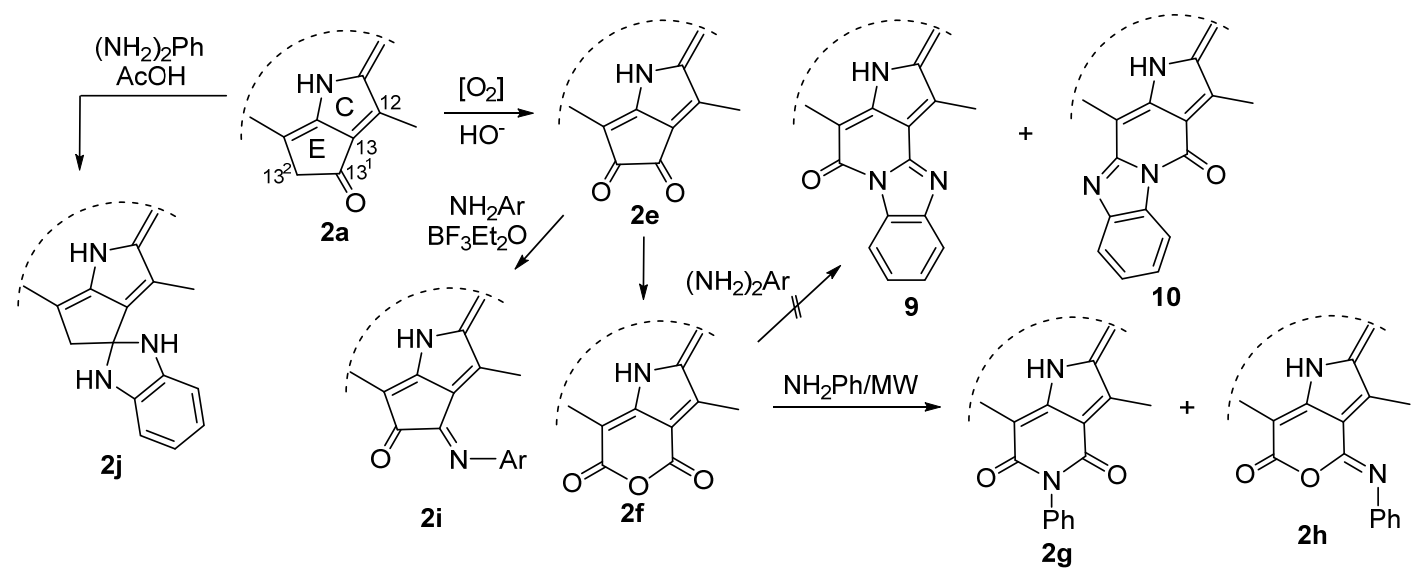

Figure 2 Reaction of the carbonyl group of exocyclic ring with aromatic amine 


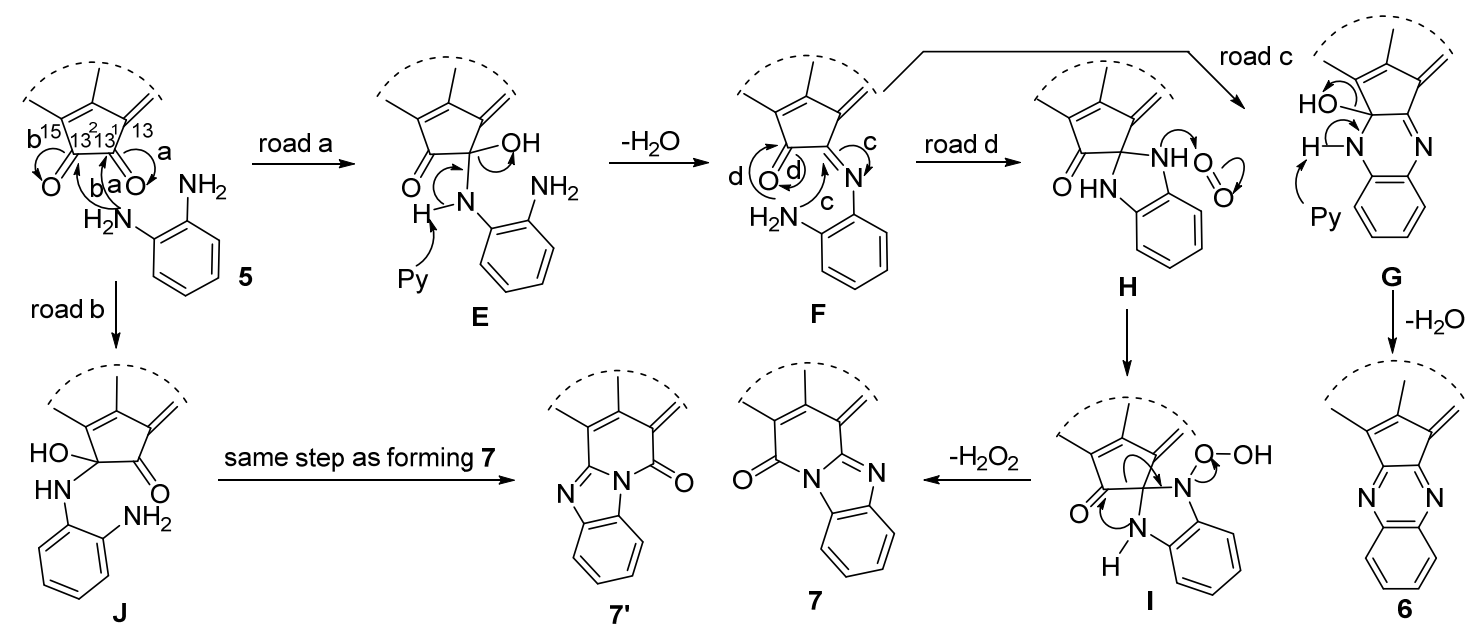

Figure 3 Forming process of quinoxaline or benzimidazol-fused chlorins based on the reaction of 5 with OPD

Specifically, the intense $Q_{\mathrm{y}}, Q_{\mathrm{x}}$ and Soret bands are situated at $780 \sim 650,600 \sim 500$ and $460 \sim 300 \mathrm{~nm}$, respectively, among which the absorption wavelength of $Q_{\mathrm{y}}$ band determined by transition dipole moments along the molecular $y$-axes (Scheme 1) is an important parameter for the application of chlorophyll. ${ }^{[13-14]}$ Therefore, improvement of $\pi$-electron system by the structural modification around the exocyclic ring has already become a main approach for acquiring tetrapyrrolic macrocycle compounds with excellent optical property. ${ }^{[15]}$

For various types of degradation products of chlorophyll, the imidazolization by condensation of formyl or ketone group with aromatic o-diamine at 12-, 13- and 15-position as well as on the E-ring gave rise to a red shift at their redmost $Q_{\mathrm{y}}$ maxima (Figure $4, \mathrm{UV}-\mathrm{Vis}$ ). It is noteworthy that such similar modifications brought about clear different shift ranges $\left(\Delta Q_{\mathrm{y}}\right)$ toward longer wavelength, for example in $\mathbf{2 b} \rightarrow \mathbf{3}\left(\Delta Q_{\mathrm{y}}=5 \mathrm{~nm}\right), \mathbf{2 b} \rightarrow \mathbf{1 4}$ $\left(\Delta Q_{\mathrm{y}}=15 \mathrm{~nm}\right)$ and $\mathbf{2 d} \rightarrow \mathbf{1 0}\left(\Delta Q_{\mathrm{y}}=55 \mathrm{~nm}\right)$. The fluorescence spectra of these chlorins have the typical features of chlorophyll-a derivatives, involving strong emission bands with normal Stocks shift (3: $14 \mathrm{~nm} ; \mathbf{8 :} 13 \mathrm{~nm} ; 14: 14 \mathrm{~nm})$.

These results clearly show that the changes in $Q_{\mathrm{y}}$ bands caused from the introduction of heterocyclic ring were correlated with the type of parent ring, connection location and structure of aromatic diamine (Figure 5). The benimidazolization of $\mathbf{2 b}$ at 12-position moved its redmost $\left(Q_{\mathrm{y}}\right)$ absorption $(668 \mathrm{~nm})$ to longer wavelength for $5 \mathrm{~nm}$, namely, the $Q_{\mathrm{y}}$ bands of the imidazolized chlorins 3 situated at $694 \mathrm{~nm}$. Similarly, the $Q_{\mathrm{y}}$ band of 4, substitutedwith naphthoimidazolyl group, also moved toward longer wavelength, such as in $\mathbf{2 b} \rightarrow \mathbf{4}\left(\Delta Q_{\mathrm{y}}=9 \mathrm{~nm}\right)$. However, the $Q_{\mathrm{y}}$ band of chlorin $\mathbf{1 4}$ which is derived from the condensation of $\mathbf{2 b}$ with 3,4-diaminobenzophenone, even appeared at $704 \mathrm{~nm}$ that bathochromically shifts by $15 \mathrm{~nm}$. This result showed that the substituent effect of benzimidazolyl group, which extends the $\pi$-electron delocalization of macrocyclic molecule, was higher than that of the original formyl group. Another reason was that the two planes of chlorin ring and substituted heterocycle, connected in
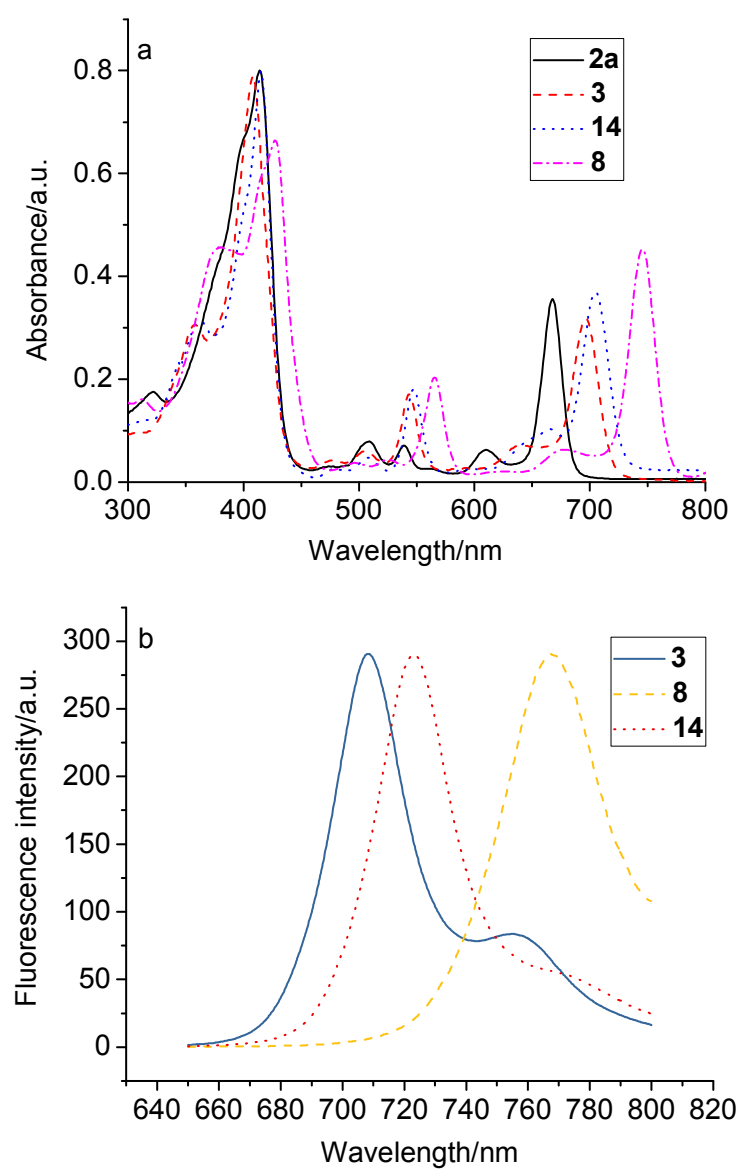

Figure 4 Comparative electronic absorption spectra of 2a, 3, 8 and 14 (UV-Vis), and the normalized fluorescence spectra of compounds $3\left(\lambda_{\mathrm{ex}}=412 \mathrm{~nm}\right), 8\left(\lambda_{\mathrm{ex}}=429 \mathrm{~nm}\right)$ and $14\left(\lambda_{\mathrm{ex}}=441\right.$ $\mathrm{nm})(\mathrm{FL})$

biphenyl type, could not deflect freely due to the electrostatic interaction between $\mathrm{C} 13^{1}$-carbonyl and the proton jointed to the benzimidazole ring to be able to maintain a coplane to some degree.

It seems hard to understand that the comparable structural transformations at identical site could enable the $Q_{\mathrm{y}}$ absorption of products to move toward the direction of 


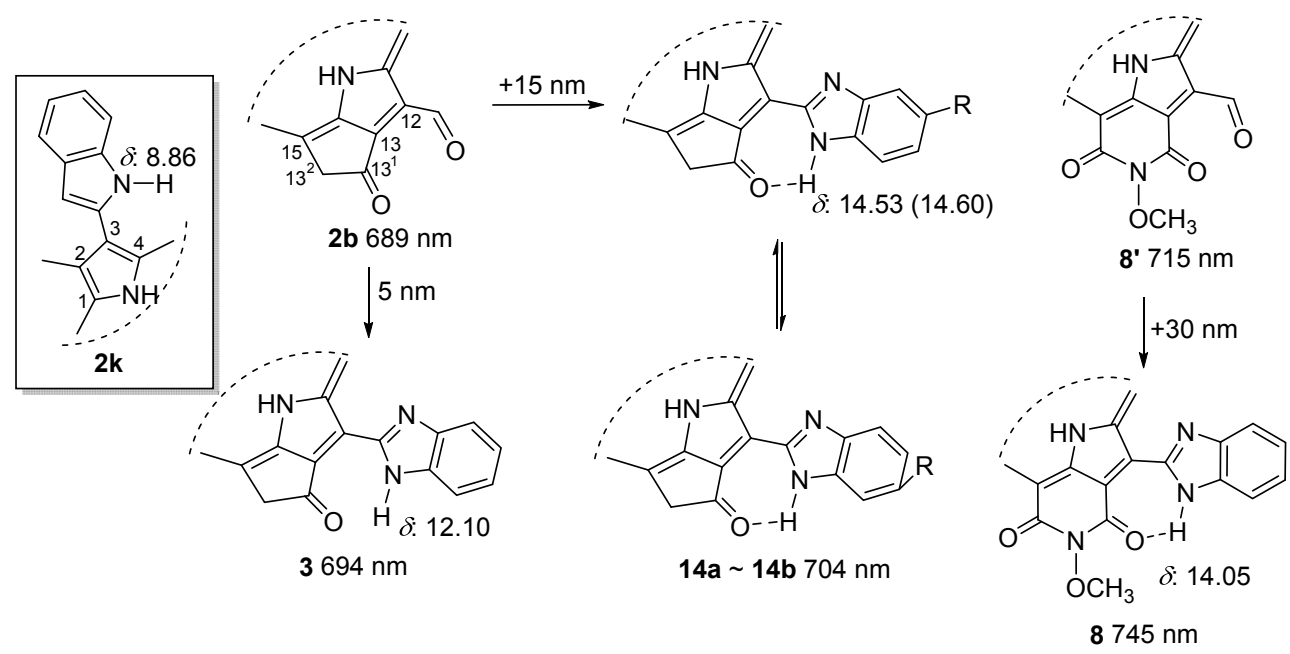

Figure 5 Substituent effect on the $Q_{\mathrm{y}}$ maxima caused by non-covalent interaction at C-subring

longer wavelengths in a completely different range. Actually, the red shift at $Q_{\mathrm{y}}$ band for $\mathbf{1 4}$ mainly benefited from a stronger electrostatic interaction between $\mathrm{C} 13^{1}$-carbonyl and C12-substituent which fully ensured the coplanarity of C12-heterocyclic substituent with parent ring, thus efficiently extends their $\pi$-electron delocalization system. The ${ }^{1} \mathrm{H}$ NMR spectra of 12-benzimidazolyl-substituted chlorins showed a characteristic downfield-shift signal ascribable to benzimidazole-H at $\delta 12.10$ for $3, \delta 11.19$ for 4 and $\delta 14.53$ (14.60) for 14, respectively. By comparison, the chemical shift of the proton without involving the magnetic anisotropy effect from carbonyl group attached to nitrogen atom of indole ring in chlorin $\mathbf{2 k}$ was just situated at $\delta 8.86$ (the framed diagram in Figure 5) ${ }^{[12]}$. These great differences indicated that there was a powerful non-covalent interaction that was similar to the intramolecular hydrogen bond, because the chemical shift of the hydrogen bonded proton tends to appear at more substantially downfield-shifted region. Another evidence to testify the formation of this hydrogen bond came from the tautomerism of 14a and $\mathbf{1 4 b}$, which were severely restricted by this non-covalent interaction and showed two tautomers in proportion of $9: 7$ in ${ }^{1} \mathrm{H}$ NMR spectra. In other chlorin analogs that possess this electrostatic interaction such as in $8\left(\delta_{\mathrm{N}-\mathrm{H}}\right.$ 14.05), the introduction of the heterocyclic substituent induced a large red shift of $Q_{\mathrm{y}}$ maxima $\left[\mathbf{8}^{\prime} \rightarrow \mathbf{8}\left(\Delta Q_{\mathrm{y}}=30\right.\right.$ $\mathrm{nm})]^{[16]}$.

The conversions on the exocyclic ring of chlorins, from pyropheophorbide-a to purpurin-18 imide carbon framework, could lead to dramatically shift at their $Q_{\mathrm{y}}$ absorption wavelength $\left(\right.$ e.g. $\left.\mathbf{3} \rightarrow \mathbf{8}, \Delta Q_{\mathrm{y}}=51 \mathrm{~nm}\right)$. The benimidazolization in cyclization manner for chlorins also induced a remarkable red shift of their $Q_{\mathrm{y}}$ maxima (e.g. $\mathbf{5} \rightarrow \mathbf{7}, \Delta Q_{\mathrm{y}}=$ $60 \mathrm{~nm}$ ). In the former case, the formation of six-membered cycloheximide structure effectively enlarges the conjugation system of macrocyclic molecule, whereas for the latter, the incorporation of rigidly connected aromatic system can cause a distortion of chlorin macrocycle plane, which is supposed to be one of the reasons of their unique photophysical characteristics ${ }^{[3]}$. Therefore, the construction of coplanar conjugate system along $y$-axis by connection or fusion way can efficiently prolong the $Q_{\mathrm{y}}$ maximal band of chlorins. The chlorins with fused and attached two benimidazol units even exhibited their $Q_{\mathrm{y}}$ bands in near-infrared region (765 nm for 7, $768 \mathrm{~nm}$ for 12), significantly bathochromically shifted $\left(\Delta Q_{\mathrm{y}}=97 \mathrm{~nm}\right.$ for $7, \Delta Q_{\mathrm{y}}$ $=100 \mathrm{~nm}$ for 12) as compared to the starting material $\mathbf{1}$ $(668 \mathrm{~nm})$.

\section{Conclusions}

The aromatic ring-fused imidazolizations of chlorins related to chlorophyll were synthesized by using the condensation of formyl group and $\alpha$-diketone moiety on periphery with various aromatic $o$-diamines based on PhillpsLadenburg-like reaction. The aromatic ring-fused imidazole structural unit was introduced at 12-position and on the exocyclic ring in connection or fusion way, respectively, affording a series of new chlorophyllous chlorins that contain aryl-fused imidazol unit. The optical properties of imidazolized chlorins were closely related to the substituted sites of heterocyclyl groups, the form of connection and the framework of exocyclic ring. The introduction of aryl-fused imidazole ring enabled to keep coplane with chromophore, which gave rise to a distinct red shift for the redmost $Q_{\mathrm{y}}$ maxima of chlorins. These heterocyclizations of chlorins with basic skeleton of chlorophyll provided a more extensive synthetic route for acquiring novel tetrapyrrole macrocycle compounds with potential applications.

\section{Experimental section}

\subsection{General}

The UV-vis spectra were taken with a Unicam SP 800 spectrophotometer. The ${ }^{1} \mathrm{H}$ NMR spectra were recorded with a Varian 400 spectrometer. Mass spectra were recorded by a JMX-DX300. The elemental analyses were performed on a Perkin-Elmer 240 microanalyzer. Melting points were determined with a WRS-1B melting-point apparatus and were uncorrected. Methyl pheophorbide-a (1) was obtained according to Smith's method ${ }^{[9]}$. All chemical 
reagents were purchased from Merck, Fluka and Aldrich chemical companies, and purified by using standard methods.

4.2 Synthesis of methyl 12-benzimidazolyl-12-demethylpyropheophorbide-a (3)

To a solution of methyl 12-formylpyropheophorbide-a $\mathbf{2 b}^{[11 \mathrm{a}]}(152 \mathrm{mg}, 0.270 \mathrm{mmol})$ in pyridine $(5 \mathrm{~mL})$ containing TFA $(0.1 \mathrm{~mL}), o$-phenylenediamine $(30 \mathrm{mg}, 0.271$ mmol) was added individually, and the reaction mixture stirred at $50{ }^{\circ} \mathrm{C}$ for $20 \mathrm{~min}$. The mixture was poured into water $(200 \mathrm{~mL})$ and extracted with $\mathrm{CH}_{2} \mathrm{Cl}_{2}(25 \mathrm{~mL} \times 3)$. The combined extracts were washed with $1 \%$ aqueous acetic acid $(30 \mathrm{~mL} \times 2)$, and water $(40 \mathrm{~mL} \times 2)$, which were then dried over sodium sulfate. The solvent was removed under reduced pressure. The residue was chromatographed on a silica column with hexane/ethyl acetate $(V: V=4$ :

1) as eluent to give $114 \mathrm{mg}$ of $3(0.176 \mathrm{mmol}, 65 \%$ yield $)$ as a green solid. m.p. $267 \sim 269{ }^{\circ} \mathrm{C}$; UV-vis $\left(\mathrm{CH}_{2} \mathrm{Cl}_{2}\right) \lambda_{\max }$ (relative intensity): 412 (1.00), 510 (0.94), 544 (0.14), 609 (0.09), 694 (0.51) nm; ${ }^{1} \mathrm{H}$ NMR (400 MHz, $\left.\mathrm{CDCl}_{3}\right) \delta$ : $12.10(\mathrm{~s}, 1 \mathrm{H}, 12-\mathrm{NH}), 10.71,8.85,8.06$ (each s, 3H, meso-H), $7.91 \sim 8.04(\mathrm{~m}, 1 \mathrm{H}, \mathrm{Ar}-\mathrm{H}), 7.78(\mathrm{dd}, J=18.4,11.6$ $\mathrm{Hz}, 1 \mathrm{H}, 3 \mathrm{a}-\mathrm{H}), 7.58 \sim 7.61(\mathrm{~m}, 1 \mathrm{H}, \mathrm{Ar}-\mathrm{H}), 7.35 \sim 7.43(\mathrm{~m}$, $2 \mathrm{H}, \mathrm{Ar}-\mathrm{H}), 6.20(\mathrm{~d}, J=18.4 \mathrm{~Hz}, 1 \mathrm{H}$, trans $-3 \mathrm{~b}-\mathrm{H}), 6.12(\mathrm{~d}$, $J=11.6 \mathrm{~Hz}, 1 \mathrm{H}$, cis-3b-H), 4.96 (d, $J=19.8 \mathrm{~Hz}, 1 \mathrm{H}$, $\left.13^{2}-\mathrm{H}\right), 4.69$ (d, $\left.J=19.8 \mathrm{~Hz}, 1 \mathrm{H}, 13^{2}-\mathrm{H}\right), 4.25$ (q, $J=7.5$ $\mathrm{Hz}, 1 \mathrm{H}, 18-\mathrm{H}), 4.07$ (d, $J=9.1 \mathrm{~Hz}, 17-\mathrm{H}), 3.67,3.16,3.03$ (each s, each $\left.3 \mathrm{H}, \mathrm{OCH}_{3}+\mathrm{CH}_{3}\right), 3.53(\mathrm{q}, J=7.5 \mathrm{~Hz}, 2 \mathrm{H}$, $8 \mathrm{a}-\mathrm{H}), 2.73 \sim 2.52(\mathrm{~m}, 2 \mathrm{H}, 17 \mathrm{a}+17 \mathrm{~b}-\mathrm{H}), 2.45 \sim 2.28(\mathrm{~m}$, $2 \mathrm{H}, 17 \mathrm{a}+17 \mathrm{~b}-\mathrm{H}), 1.89$ (d, $\left.J=7.3 \mathrm{~Hz}, 3 \mathrm{H}, 18-\mathrm{CH}_{3}\right), 1.60$ (t, $J=7.5 \mathrm{~Hz}, 3 \mathrm{H}, 8-\mathrm{CH}), 0.45$ (br s, $1 \mathrm{H}, \mathrm{NH}),-0.68$ (br $\mathrm{s}, 1 \mathrm{H}, \mathrm{NH}) ;{ }^{13} \mathrm{C}$ NMR (151 MHz, Chloroform- $d$ ) $\delta: 194.95$, $173.53,159.77,152.72,148.21,147.62,145.87,142.91$, $138.36,136.13,135.83,135.79,132.65,130.34 \sim 129.43$ (m), 128.64, 125.62, 122.51, 115.38 114.18 (m), 107.56, $106.04,96.20,93.30,51.75,50.82,50.13,31.92,31.22$, $22.70,19.73,19.18,16.80,14.19,14.12,11.75,11.01$; EI-MS $m / z$ : $651.3\left(\mathrm{M}+\mathrm{H}^{+}\right)$; HRMS calcd for $\mathrm{C}_{40} \mathrm{H}_{38} \mathrm{~N}_{6} \mathrm{O}_{3}$ $\left(\mathrm{M}+\mathrm{H}^{+}\right)$651.3078; found 651.3077. Anal. calcd for $\mathrm{C}_{40} \mathrm{H}_{38} \mathrm{~N}_{6} \mathrm{O}_{3}$ : C 73.82, H 5.89, N 12.91; found $\mathrm{C} 73.69, \mathrm{H}$ 5.67, N 13.07.

\subsection{Syntheisi of methyl 12-naphthoimidazolyl-12-} demethylpyropheophorbide-a (4)

Compound 4 was obtained in yield of $61 \%$ according to the method of preparing compound 3. m.p. $275 \sim 278{ }^{\circ} \mathrm{C}$; $\mathrm{UV}$-vis $\left(\mathrm{CH}_{2} \mathrm{Cl}_{2}\right) \lambda_{\max }$ (relative intensity): 417 (1.00), 510 (0.46), 556 (0.23), 617 (0.23), 698 (0.63) nm; ${ }^{1} \mathrm{H}$ NMR $\left(400 \mathrm{MHz}, \mathrm{CDCl}_{3}\right) \delta: 11.19$ (br s, $\left.1 \mathrm{H}, 12 \mathrm{a}-\mathrm{H}\right), 9.74,8.69$, 7.80 (each s, 3H, meso-H), 8.08 (s, 1H, Ar-H), 8.00 (s, 1H, Ar-H), 7.66 (dd, $J=18.2,12.2 \mathrm{~Hz}, 1 \mathrm{H}, 3 \mathrm{a}-\mathrm{H}), 7.52 \sim 7.27$ (m, 3H, Ar-H), $7.19 \sim 7.09$ (m, 1H, Ar-H), 6.10 (d, $J=$ $18.2 \mathrm{~Hz}, 1 \mathrm{H}$, trans-3b-H), 6.07 (d, $J=12.2 \mathrm{~Hz}, 1 \mathrm{H}$, cis-3b-H), $4.81\left(\mathrm{~d}, J=19.5 \mathrm{~Hz}, 1 \mathrm{H}, 13^{2}-\mathrm{H}\right), 4.48(\mathrm{~d}, J=$ $19.5 \mathrm{~Hz}, 1 \mathrm{H}, 13^{2}-\mathrm{H}$ ), 4.20 (q, $\left.J=7.3 \mathrm{~Hz}, 1 \mathrm{H}, 18-\mathrm{H}\right), 4.05$ (d, $J=9.4 \mathrm{~Hz}, 1 \mathrm{H}, 17-\mathrm{H}), 3.53$ (q, $J=7.5 \mathrm{~Hz}, 2 \mathrm{H}, 8 \mathrm{a}-\mathrm{H})$, $3.72,3.04,2.81$ (each s, each $\left.3 \mathrm{H}, \mathrm{CH}_{3}+\mathrm{OCH}_{3}\right), 2.83 \sim$ $2.56(\mathrm{~m}, 2 \mathrm{H}, 17 \mathrm{a}+17 \mathrm{~b}-\mathrm{H}), 2.52 \sim 2.39(\mathrm{~m}, 2 \mathrm{H}, 17 \mathrm{a}+$ $17 \mathrm{~b}-\mathrm{H}), 1.93$ (d, $\left.J=7.2 \mathrm{~Hz}, 3 \mathrm{H}, 18-\mathrm{CH}_{3}\right), 1.61$ (t, $J=7.5$ $\mathrm{Hz}, 3 \mathrm{H}, 8 \mathrm{a}-\mathrm{CH}_{3}$ ), 0.86 (br s, $\left.1 \mathrm{H}, \mathrm{NH}\right),-0.75$ (br s, $1 \mathrm{H}$, $\mathrm{NH}) ;{ }^{13} \mathrm{C}$ NMR (151 MHz, Chloroform- $d$ ) $\delta: 174.57$, $174.09,163.46,155.07,154.89,150.80,150.30,150.05$, $145.86,143.09,143.00,142.04,140.34,139.83,139.77$, $135.51,134.88,132.46,131.92,129.75,126.96,124.24$, $112.87,112.28,111.62,111.15,109.52,104.41,100.39$, $97.74,92.36,90.63,51.69,51.00,49.38,31.09,21.09$, $19.25,19.10,17.32,16.94,14.58,10.95$; EI-MS m/z: 701.1 $\left(\mathrm{M}+\mathrm{H}^{+}\right)$. Anal. calcd for $\mathrm{C}_{44} \mathrm{H}_{40} \mathrm{~N}_{6} \mathrm{O}_{3}$ : C 75.41, H 5.75, N 11.99; found C 75.53, H 5.63, N 11.85 .

4.4 Synthesis of methyl 12-benzimidazolyl-1320xo12-demethylpyropheophorbide-a (5)

To a THF solution $(25 \mathrm{~mL})$ of chlorin 3 (168 mg, 0.258 $\mathrm{mmol})$, the aqueous solution $(5 \mathrm{~mL})$ of $\mathrm{LiOH}(1.2 \mathrm{~g})$ and methanol $(15 \mathrm{~mL})$ were sequentially added. This mixture was violently stirred in open system in dark for $3 \mathrm{~h}$, which was then poured into cool water, adjusted to $\mathrm{pH} 3$ with diluted hydrochloric acid and further extracted with dichloromethane $(25 \mathrm{~mL} \times 2)$. The combined extracts were washed with water, dried over anhydrous $\mathrm{Na}_{2} \mathrm{SO}_{4}$ and treated with $\mathrm{CH}_{2} \mathrm{~N}_{2}$ for a short time (approximately $2 \mathrm{~min}$ ). After evaporation in vacuo, the residue was purified on chromatography on a silica gel column with hexane-ethyl acetate $(V: V=5: 1)$ as eluent to give $88 \mathrm{mg}$ of $5(0.132$ mmol, 71\%) as an orange-red solid. m.p. $>300{ }^{\circ} \mathrm{C}$; UV-vis $\left(\mathrm{CH}_{2} \mathrm{Cl}_{2}\right) \lambda_{\max }$ (relative intensity): 406 (1.00), 534 (0.05), 582 (0.16), 643 (0.06), 709 (0.31) nm; ${ }^{1} \mathrm{H}$ NMR (400 MHz, $\left.\mathrm{CDCl}_{3}\right) \delta: 13.24(\mathrm{~s}, 1 \mathrm{H}, \mathrm{NH}), 9.70,9.40,8.70$ (each s, each $1 \mathrm{H}$, meso-H), 8.09 (d, $J=7.2 \mathrm{~Hz}, 1 \mathrm{H}, \mathrm{Ar}-\mathrm{H}), 8.05$ (dd, $J=$ 17.9, $11.3 \mathrm{~Hz}, 3 \mathrm{a}-\mathrm{H}), 7.61$ (t, $J=7.4 \mathrm{~Hz}, 1 \mathrm{H}$, Ar-H), $7.54 \sim 7.45$ (m, 1H, Ar-H), $7.06(\mathrm{t}, J=7.1 \mathrm{~Hz}, 1 \mathrm{H}, \mathrm{Ar}-\mathrm{H})$, $6.27(\mathrm{~d}, J=17.9 \mathrm{~Hz}, 1 \mathrm{H}$, trans-3b-H), $6.16(\mathrm{~d}, J=11.3 \mathrm{~Hz}$, cis-3b-H), 4.91 (d, $J=8.8 \mathrm{~Hz}, 1 \mathrm{H}, 17-\mathrm{H}), 4,46$ (q, $J=7.4$ $\mathrm{Hz}, 1 \mathrm{H}, 18-\mathrm{H}$ ), 3.69 (t, $J=7.6 \mathrm{~Hz}, 8 \mathrm{a}-\mathrm{H}), 3.58,3.41,3.27$ (each s, each $\left.3 \mathrm{H}, \mathrm{CH}_{3}+\mathrm{OCH}_{3}\right), 2.82 \sim 2.59(\mathrm{~m}, 2 \mathrm{H}, 17 \mathrm{a}+$ $17 \mathrm{~b}-\mathrm{H}), 2.35 \sim 2.25(\mathrm{~m}, 1 \mathrm{H}, 17 \mathrm{a}+17 \mathrm{~b}-\mathrm{H}), 1.07 \sim 1.97(\mathrm{~m}$, $1 \mathrm{H}, 17 \mathrm{a}+17 \mathrm{~b}-\mathrm{H}), 1.81\left(\mathrm{~d}, J=7.2 \mathrm{~Hz}, 3 \mathrm{H}, 18-\mathrm{CH}_{3}\right), 1.70$ (t, $J=7.6 \mathrm{~Hz}, 3 \mathrm{H}, 8-\mathrm{CH}_{3}$ ), -0.02 (br s, $\left.1 \mathrm{H}, \mathrm{NH}\right),-1.27$ (br s, $1 \mathrm{H}, \mathrm{NH}) ;{ }^{13} \mathrm{C}$ NMR (151 MHz, Chloroform-d) $\delta$ : $210.85,190.62,182.21,176.39,173.74,173.22,166.36$, $152.63,151.69,150.74,144.93,144.83,144.10,137.35$, $137.22,136.40,133.34,132.28,128.40,128.06,123.33$, $123.05,121.26,119.35,115.21,110.77,107.48,103.94$, $99.76,95.55,69.51,65.28,52.22,51.73,32.33,23.61$, 19.21, 16.52, 11.90, 11.02; EI-MS $m / z: 665.4\left(\mathrm{M}+\mathrm{H}^{+}\right)$. Anal.calcd for $\mathrm{C}_{40} \mathrm{H}_{36} \mathrm{~N}_{6} \mathrm{O}_{4}$ : C 72.27, $\mathrm{H}$ 5.46, N 12.64; found C 72.43, H 5.67, N 12.49.

4.5 Synthesis of 12-benzimidazolyl-quinoxaleno[2,3-n]pheophorbide-a methyl ester (6) and 12-benzimidazolyl-benzimidazolo[2,1-n]purpurin-18 $13^{1}$-imino$13^{2}$-imide methyl ester (7)

Chlorin diketon 5 (149 mg, $0.224 \mathrm{mmol})$ and $o$-phenylenediamine $(100 \mathrm{mg}, 0.926 \mathrm{mmol})$ were dissolved in THF $(10 \mathrm{~mL})$ containing TFA $(0.1 \mathrm{~mL})$. The resulted reac- 
tion mixture was stirring at room temperature under $\mathrm{N}_{2}$ atmosphere for $48 \mathrm{~h}$, which was poured into water (200 $\mathrm{mL})$ and extracted with $\mathrm{CH}_{2} \mathrm{Cl}_{2}(25 \mathrm{~mL} \times 3)$. The combined extracts were washed with $1 \%$ aqueous sodium bicarbonate, then with water, dried over sodium sulfate, and the solvent was removed under reduced pressure. The residue was chromatographed on a silica column with hexane-ethyl acetate $(V: V=4: 1)$ as eluent to give $46 \mathrm{mg}$ of $6(0.063 \mathrm{mmol}, 28 \%)$ as a yellowish-brown solid and 64 $\mathrm{mg}$ of $7(0.085 \mathrm{mmol}, 38 \%)$ as a bottle green solid.

6: m.p. $293 \sim 296{ }^{\circ} \mathrm{C}$; UV-vis $\left(\mathrm{CH}_{2} \mathrm{Cl}_{2}\right) \lambda_{\max }$ (relative intensity): 451 (1.00), 550 (0.08), 605 (0.06), 681 (0.13), 737 (0.62) nm; ${ }^{1} \mathrm{H}$ NMR (400 MHz, $\mathrm{CDCl}_{3}$ ) $\delta: 11.18$ (br s, $1 \mathrm{H}, 12-\mathrm{NH}), 9.37,8.72,7.68$ (each s, 3H, meso-H), 8.14 (dd, $J=17.8,11.5 \mathrm{~Hz}, 3 \mathrm{a}-\mathrm{H}), 7.98$ (dd, $J=8.4,4.2 \mathrm{~Hz}, 1 \mathrm{H}$, Ar-H), 7.85 7.77(m, 1H, Ar-H), $7.61(\mathrm{dd}, J=8.4,4.2 \mathrm{~Hz}$, $2 \mathrm{H}, \mathrm{Ar}-\mathrm{H}), 7.51 \sim 7.45(\mathrm{~m}, 1 \mathrm{H}, \mathrm{Ar}-\mathrm{H}), 7.33$ (br s, 2H, Ar-H), 7.03 (br s, 1H, Ar-H), 6.31(d, J=17.8 Hz, 1H, trans-3b- H), 6.21 (dd, $J=11.5 \mathrm{~Hz}, 1 \mathrm{H}$, cis-3b-H), 4.74 (d, $J=7.4 \mathrm{~Hz}, 1 \mathrm{H}, 17-\mathrm{H}), 4.21$ (q, $J=7.2 \mathrm{~Hz}, 1 \mathrm{H}, 18-\mathrm{H}), 3.71$, $3.00,2.43$ (each s, each $\left.3 \mathrm{H}, \mathrm{CH}_{3}+\mathrm{OCH}_{3}\right), 3.45$ (dq, $J=$ 14.3, $7.4 \mathrm{~Hz}, 1 \mathrm{H}, 8 \mathrm{a}-\mathrm{H}), 3.25(\mathrm{dq}, J=14.3,7.4 \mathrm{~Hz}, 1 \mathrm{H}$, $8 \mathrm{a}-\mathrm{H}), 3.25 \sim 3.11(\mathrm{~m}, 1 \mathrm{H}, 17 \mathrm{a}+17 \mathrm{~b}-\mathrm{H}), 2.88 \sim 2.76(\mathrm{~m}$, $1 \mathrm{H}, 17 \mathrm{a}+17 \mathrm{~b}-\mathrm{H}), 2.55 \sim 2.68(\mathrm{~m}, 1 \mathrm{H}, 17 \mathrm{a}+17 \mathrm{~b}-\mathrm{H}), 2.11$ $\left(\mathrm{d}, J=7.2 \mathrm{~Hz}, 3 \mathrm{H}, 18-\mathrm{CH}_{3}\right), 1.47$ (t, $J=7.4 \mathrm{~Hz}, 3 \mathrm{H}$, $\left.8 \mathrm{a}-\mathrm{CH}_{3}\right), 1.02$ (br s, $\left.1 \mathrm{H}, \mathrm{NH}\right),-0.79($ br s, $1 \mathrm{H}, \mathrm{NH}) ;{ }^{13} \mathrm{C}$ NMR (151 MHz, Chloroform- $d$ ) $\delta: 174.75,174.17,166.36$, $161.99,157.46,153.91,151.51,150.92,149.85,146.23$, $144.08,143.88,143.42,141.46,138.96,137.04,136.03$, $135.93,134.27,131.29,129.94,129.78,129.08,128.52$, $128.22,127.88,127.76,127.66,127.40,123.41,121.99$, 114.94, 108.53, 103.10, 99.72, 94.09, 69.99, 63.76, 51.65, 49.43, 32.82, 23.42, 16.22, 14.12, 11.90, 10.30; EI-MS $m / z$ : $737.4\left(\mathrm{M}+\mathrm{H}^{+}\right)$; HRMS calcd for $\mathrm{C}_{46} \mathrm{H}_{41} \mathrm{~N}_{8} \mathrm{O}_{2} \quad(\mathrm{M}+$ $\mathrm{H}^{+}$) 737.3347; found 737.3344. Anal. calcd for $\mathrm{C}_{46} \mathrm{H}_{40^{-}}$ $\mathrm{N}_{8} \mathrm{O}_{2}$ : C 74.98, H 5.47, N 15.21; found C 75.16, H 5.60, N 15.29 .

7: m.p. $271 \sim 273{ }^{\circ} \mathrm{C}$; UV-vis $\left(\mathrm{CH}_{2} \mathrm{Cl}_{2}\right) \lambda_{\max }$ (relative intensity): 447 (1.00), 501 (0.10), 536 (0.08), 578 (0.34), 700 (0.16), 765 (0.71) nm; ${ }^{1} \mathrm{H}$ NMR (400 MHz, $\left.\mathrm{CDCl}_{3}\right) \delta$ : 11.27 (br s, 1H, 12-NH), 8.85, 8.78, 8.11 (each s, 3H, meso-H), 7.78 (dd, $J=17.9,11.5 \mathrm{~Hz}, 1 \mathrm{H}, 3 \mathrm{a}-\mathrm{H}), 7.98 \sim$ $7.62(\mathrm{~m}, 3 \mathrm{H}, \mathrm{Ar}-\mathrm{H}), 7.55 \sim 7.52(\mathrm{~m}, 3 \mathrm{H}, \mathrm{Ar}-\mathrm{H}), 7.42 \sim 7.40$ (m, 2H, Ar-H), 6.31 (d, J=17.9 Hz, 1H, trans-3b-H), 6.17 (d, $J=11.5 \mathrm{~Hz}, 1 \mathrm{H}$, cis-3b-H), 5.30 (d, $J=7.5 \mathrm{~Hz}, 1 \mathrm{H}$, 17-H), 4.17 (q, $J=7.3 \mathrm{~Hz}, 1 \mathrm{H}, 18-\mathrm{H}), 3.64,3.15,2.75$ (each s, each $3 \mathrm{H}, \mathrm{CH}_{3}+\mathrm{OCH}_{3}$ ), $3.40 \sim 3.58(\mathrm{~m}, 2 \mathrm{H}, 8 \mathrm{a}-\mathrm{H})$, $2.84 \sim 2.72(\mathrm{~m}, 2 \mathrm{H}, 17 \mathrm{a}+17 \mathrm{~b}-\mathrm{H}), 2.55 \sim 2.47(\mathrm{~m}, 1 \mathrm{H}, 17 \mathrm{a}$ $+17 \mathrm{~b}-\mathrm{H}), 2.12 \sim 2.00(\mathrm{~m}, 1 \mathrm{H}, 17 \mathrm{a}+17 \mathrm{~b}-\mathrm{H}), 1.85(\mathrm{~d}, J=$ $\left.7.1 \mathrm{~Hz}, 3 \mathrm{H}, 18-\mathrm{CH}_{3}\right), 1.57\left(\mathrm{t}, J=7.0 \mathrm{~Hz}, 3 \mathrm{H}, 8 \mathrm{a}-\mathrm{CH}_{3}\right), 0.81$ (br s, $1 \mathrm{H}, \mathrm{NH}), 0.71($ br s, $1 \mathrm{H}, \mathrm{NH})$; EI-MS $m / z: 753.2$ $\left(\mathrm{M}+\mathrm{H}^{+}\right)$. Anal.calcd for $\mathrm{C}_{46} \mathrm{H}_{40} \mathrm{~N}_{8} \mathrm{O}_{3}: \mathrm{C} 73.39, \mathrm{H} 5.36, \mathrm{~N}$ 14.88; found C 73.51, H 5.49, N 14.95 .

4.6 Synthesis of 12-benzimidazolyl-12-demethyl- $N$ methyloxyl purpurinimide methyl ester (8)

Chlorin diketon 5 (104 mg, $0.157 \mathrm{mmol})$ was first dissolved in pyridine $(20 \mathrm{~mL})$, and a solution of sodium methoxide in methanol $(1 \mathrm{~mol} / \mathrm{L}, 4 \mathrm{~mL})$ was added, then the reaction mixture was stirred at room temperature for 2 h. The $\mathrm{pH}$ value of the reaction mixture was adjusted to $4 \sim 5$ by adding diluted hydrochloric acid, and extracted with dichloromethane $(25 \mathrm{~mL} \times 2)$. The combined organic layers were washed with water, dried over $\mathrm{Na}_{2} \mathrm{SO}_{4}$, and evaporated in vacuo to move the low-boiling point solvent. The residue was added by large excess of hydroxylammonium chloride $(50 \mathrm{mg})$, and stirred at room temperature for $6 \mathrm{~h}$. The produced mixture was poured into cool water, adjusted to $\mathrm{pH} 3$ with diluted hydrochloric acid, and then extracted with dichloromethane $(25 \mathrm{~mL} \times 3)$. The combined extracts were washed with water, dried over anhydrous $\mathrm{Na}_{2} \mathrm{SO}_{4}$ and treated with $\mathrm{CH}_{2} \mathrm{~N}_{2}$ for a short time (approximately $2 \mathrm{~min}$ ). After evaporation in vacuo, the residue was purified on chromatography on a silica gel column with hexane-ethyl acetate $(V: V=5: 1)$ as eluent to give $88 \mathrm{mg}$ of $8(0.124 \mathrm{mmol}, 79 \%)$ as an orange-red solid. m.p. $224 \sim 227{ }^{\circ} \mathrm{C}$; UV-vis $\left(\mathrm{CH}_{2} \mathrm{Cl}_{2}\right) \lambda_{\max }$ (relative intensity): 375 (0.73), 429 (1.00), 580 (0.33), 683 (0.25), 745 (0.75) nm; ${ }^{1} \mathrm{H}$ NMR (400 MHz, $\left.\mathrm{CDCl}_{3}\right) \delta: 14.09(\mathrm{~s}, 1 \mathrm{H}$, 12-NH), 10.99, 8.79, 8.05 (each s, each $1 \mathrm{H}$, meso-H), 7.73 (br s, 1H, Ar-H), 7.62 (dd, $J=17.8,11.5 \mathrm{~Hz}, 1 \mathrm{H}, 3 \mathrm{a}-\mathrm{H})$, 7.58 (br s, 1H, Ar-H), 7.36 (br s, 2H, Ar-H), 6.20 (d, $J=$ $17.8 \mathrm{~Hz}, 1 \mathrm{H}$, trans-3b-H), $6.10(\mathrm{~d}, J=11.5 \mathrm{~Hz}, 1 \mathrm{H}$, cis-3b-H), 5.15 (d, $J=8.8 \mathrm{~Hz}, 1 \mathrm{H}, 17-\mathrm{H}), 4.18$ (q, $J=6.9$ $\mathrm{Hz}, 1 \mathrm{H}, 18-\mathrm{H}), 3.24$ (q, $J=6.6,2 \mathrm{H}, 8 \mathrm{a}-\mathrm{H}), 4.40,3.66$, 3.07, 2.93 (each s, each $\left.3 \mathrm{H}, \mathrm{CH}_{3}+\mathrm{OCH}_{3}\right), 2.92 \sim 2.78(\mathrm{~m}$, $1 \mathrm{H}, 17 \mathrm{a}+17 \mathrm{~b}-\mathrm{H}), 2.68 \sim 2.47(\mathrm{~m}, 2 \mathrm{H}, 17 \mathrm{a}+17 \mathrm{~b}-\mathrm{H})$, $2.05 \sim 1.94(\mathrm{~m}, 1 \mathrm{H}, 17 \mathrm{a}+17 \mathrm{~b}-\mathrm{H}), 1.74(\mathrm{~d}, J=6.9 \mathrm{~Hz}, 3 \mathrm{H}$, $\left.18-\mathrm{CH}_{3}\right), 1.47$ (t, $\left.J=6.6 \mathrm{~Hz}, 3 \mathrm{H}, 8-\mathrm{CH}_{3}\right), 0.88$ (br s, $1 \mathrm{H}$, $\mathrm{NH}), 0.83$ (br s, $1 \mathrm{H}, \mathrm{NH}) ;{ }^{13} \mathrm{C}$ NMR $(151 \mathrm{MHz}$, Chloroform- $d$ ) $\delta$ : 178.82, 178.58, 173.75, 162.82, 160.82, 158.92, $151.51,147.95,146.68,146.00,138.78,137.65,136.01$, $135.70,132.48,131.12,127.97,123.44,123.04,114.14$, $109.67,102.65,96.37,94.84,64.69,55.08,51.61,49.36$, $32.99,31.49,23.66,19.21,16.76,11.64,10.63$; EI-MS $m / z: 710.3\left(\mathrm{M}+\mathrm{H}^{+}\right)$. Anal. calcd for $\mathrm{C}_{41} \mathrm{H}_{39} \mathrm{~N}_{7} \mathrm{O}_{5}$ : C 69.38, H 5.54, N 13.81; found C 69.51, H 5.44, N13.77.

4.7 Synthesis of benzimidazolo[2,1-n]purpurin-18 $13^{1}$-imino- $13^{2}$-imide methyl ester $(9)$ and benzimidazolo[1,2-o]purpurin-18 $13^{3}$-imino-13 ${ }^{2}$-imide methyl ester (10)

According to the method of synthesizing compound 3, Chlorin 9 was obtained in yield of $61 \%$ by the treatment of 13-formyl substituted chlorin $2 \mathrm{c}$ with OPD for $5 \mathrm{~h}$, and Chlorin 10 was obtained in yield of $58 \%$ by the treatment of 15-formyl substituted chlorin 2d with OPD for $4 \mathrm{~h}$.

9: m.p. $>300{ }^{\circ} \mathrm{C}$; UV-vis $\left(\mathrm{CH}_{2} \mathrm{Cl}_{2}\right) \lambda_{\max }$ (relative intensity): 386 (0.88), 423 (1.00), 446 (0.78), 592 (0.28), 655 (0.18), $714(0.58) \mathrm{nm} ;{ }^{1} \mathrm{H}$ NMR (400 $\left.\mathrm{MHz}, \mathrm{CDCl}_{3}\right) \delta$ : $9.45,9.39,8.56$ (each s, each $1 \mathrm{H}$, meso-H), 8.05 (d, $J=7.1$ $\mathrm{Hz}, 2 \mathrm{H}, \mathrm{Ar}-\mathrm{H}), 7.99$ (dd, $J=17.8,12.0 \mathrm{~Hz}, 3 \mathrm{a}-\mathrm{H}), 7.53 \sim$ $7.61(\mathrm{~m}, 2 \mathrm{H}, \mathrm{Ar}-\mathrm{H}), 6.26(\mathrm{~d}, J=17.8 \mathrm{~Hz}, 1 \mathrm{H}$, trans $-3 \mathrm{~b}-\mathrm{H})$, $6.17(\mathrm{~d}, J=12.0 \mathrm{~Hz}, 1 \mathrm{H}$, cis-3b-H), 5.11 (d, $J=7.6 \mathrm{~Hz}$, 
$1 \mathrm{H}, 17-\mathrm{H}), 4.51$ (q, $J=7.4 \mathrm{~Hz}, 1 \mathrm{H}, 18-\mathrm{H}), 3.65$ (q, $J=7.6$, $2 \mathrm{H}, 8 \mathrm{a}-\mathrm{H}$ ), 2.75, 3.58, 3.38, 3.21 (each s, each $3 \mathrm{H}, \mathrm{CH}_{3}+$ $\left.\mathrm{OCH}_{3}\right), 2.98 \sim 2.86($ each m, 1H, 17a+17b-H), 2.79 2.69 (each m, 1H, 17a+17b-H), 2.49-2.37 (each m, 1H, 17a+ $17 \mathrm{~b}-\mathrm{H}), 2.07 \sim 1.98(\mathrm{~m}, 1 \mathrm{H}, 17 \mathrm{a}+17 \mathrm{~b}-\mathrm{H}), 1.85(\mathrm{~d}, J=7.3$ $\left.\mathrm{Hz}, 3 \mathrm{H}, 18-\mathrm{CH}_{3}\right), 1.68$ (t, J=7.6 Hz, 3H, 8- $\mathrm{CH}_{3}$ ), 0.70 (br s, $1 \mathrm{H}, \mathrm{NH}),-0.90$ (br s, $1 \mathrm{H}, \mathrm{NH})$.

10: m.p. $>300{ }^{\circ} \mathrm{C}$; UV-vis $\left(\mathrm{CH}_{2} \mathrm{Cl}_{2}\right) \lambda_{\max }$ (relative intensity): 375 (0.32), 427 (1.00), 487 (0.06), 577 (0.28), 730 (0.49) nm; ${ }^{1} \mathrm{H}$ NMR (400 MHz, $\left.\mathrm{CDCl}_{3}\right) \delta: 9.40,9.30,8.57$ (each s, each $1 \mathrm{H}$, meso-H), $8.75(\mathrm{dd}, J=8.8,4.1 \mathrm{~Hz}, 1 \mathrm{H}$, Ar-H), 7.93 (dd, $J=18.6,4.7 \mathrm{~Hz}, 1 \mathrm{H}, \mathrm{Ar}-\mathrm{H}), 7.88$ (dd, $J=$ 17.8, $11.5 \mathrm{~Hz}, 1 \mathrm{H}, 3 \mathrm{a}-\mathrm{H}), 7.41 \sim 7.48$ (m, 2H, Ar-H), 6.27 (d, $J=17.8,1 \mathrm{H}$, trans-3b-H), $6.13(\mathrm{~d}, J=11.5 \mathrm{~Hz}, 1 \mathrm{H}$, cis-3b-H), 5.44 (d, $J=7.2 \mathrm{~Hz}, 1 \mathrm{H}, 17-\mathrm{H}), 4.38$ (q, $J=7.4$ $\mathrm{Hz}, 1 \mathrm{H}, 18-\mathrm{H}), 3.56$ (q, $J=7.6 \mathrm{~Hz}, 2 \mathrm{H}, 8 \mathrm{a}-\mathrm{H}), 3.74,3.59$, 3.34, 3.08 (each s, each $\left.3 \mathrm{H}, \mathrm{CH}_{3}+\mathrm{OCH}_{3}\right), 2.80 \sim 2.73(\mathrm{~m}$, $1 \mathrm{H}, 17 \mathrm{a}+17 \mathrm{~b}-\mathrm{H}), 2.54-2.35(\mathrm{~m}, 2 \mathrm{H}, 17 \mathrm{a}+17 \mathrm{~b}-\mathrm{H}), 2.09 \sim$ $2.01(\mathrm{~m}, 1 \mathrm{H}, 17 \mathrm{a}+17 \mathrm{~b}-\mathrm{H}), 1.79(\mathrm{~d}, J=7.3 \mathrm{~Hz}, 3 \mathrm{H}$, $\left.18-\mathrm{CH}_{3}\right), 1.62\left(\mathrm{t}, J=7.6 \mathrm{~Hz}, 3 \mathrm{H}, 8-\mathrm{CH}_{3}\right), 0.14$ (br s, $1 \mathrm{H}$, $\mathrm{NH}$ ), 0.08 (br s, $1 \mathrm{H}, \mathrm{NH}$ ). Other analysis data were consistent with those in the literature ${ }^{[11 \mathrm{e}]}$.

4.8 Synthesis of 12-naphthoimidazolyl-quinoxaleno[2,3-n]pheophorbide-a methyl ester (11) and 12-naphthoimidazolyl-benzimidazolo[2,1-n]purpurin-18 13 $1{ }^{1}$ mino-13 ${ }^{2}$-imide methyl ester (12)

A mixture of chlorin aldehyde $2 \mathbf{b}$ (106 mg, 0.189 mmol), o-phenylenediamine (150 mg, $0.943 \mathrm{mmol})$ and TFA $(0.1 \mathrm{~mL})$ in dry pyridine was stirred at $50{ }^{\circ} \mathrm{C}$ for $1 \mathrm{~h}$, to which the aqueous solution $(5 \mathrm{~mL})$ of $\mathrm{LiOH}(1.2 \mathrm{~g})$ and methanol $(15 \mathrm{~mL})$ were added. The resulted mixture was violently stirred at room temperature in open system in dark for $3 \mathrm{~h}$, which was then poured into cool water and then extracted with dichloromethane $(25 \mathrm{~mL} \times 2)$. The combined extracts were washed with water, dried over anhydrous $\mathrm{Na}_{2} \mathrm{SO}_{4}$ and treated with $\mathrm{CH}_{2} \mathrm{~N}_{2}$ for a short time (approximately $2 \mathrm{~min}$ ). After removing the volatile solution in vacuo and adding TFA $(0.1 \mathrm{~mL})$, the obtained mixture was stirred at room temperature under $\mathrm{N}_{2}$ atmosphere for $48 \mathrm{~h}$, poured into water $(200 \mathrm{~mL})$ and extracted with $\mathrm{CH}_{2} \mathrm{Cl}_{2}(25 \mathrm{~mL} \times 3)$. The combined extracts were washed with $1 \%$ aqueous acetic acid $(30 \mathrm{~mL} \times 2)$, then with water $(40 \mathrm{~mL} \times 2)$, dried over anhydrous sodium sulfate. After evaporation in vacuo, the residue was chromatographed on a silica column with hexane-ethyl acetate $(V: V=4: 1)$ as eluent to give $46 \mathrm{mg}$ of $11(0.059 \mathrm{mmol}, 31 \%)$ as yellow solid and $34 \mathrm{mg}$ of $12(0.042 \mathrm{mmol}, 22 \%)$ as green solid.

11: m.p. $>300{ }^{\circ} \mathrm{C}$; UV-vis $\left(\mathrm{CH}_{2} \mathrm{Cl}_{2}\right) \lambda_{\max }$ (relative intensity): 449 (1.00), 552 (0.06), 610 (0.07), 683 (0.14), $740(0.56) \mathrm{nm} ;{ }^{1} \mathrm{H}$ NMR (400 MHz, $\left.\mathrm{CDCl}_{3}\right) \delta: 10.44$ (br s, $1 \mathrm{H}, 12-\mathrm{NH}$ ), 8.95, 8.48, 7.20 (each s, 3H, meso-H), 8.00 (br s, 1H, Ar-H), 7.88 (t, $J=8.4 \mathrm{~Hz}, 2 \mathrm{H}, \mathrm{Ar}-\mathrm{H}), 7.64 \sim$ $7.75(\mathrm{~m}, 1 \mathrm{H}, \mathrm{Ar}-\mathrm{H}), 7.70$ (dd, $J=17.8,11.5 \mathrm{~Hz}, 1 \mathrm{H}, 3 \mathrm{a}-\mathrm{H})$, $7.61 \sim 7.72(\mathrm{~m}, 2 \mathrm{H}, \mathrm{Ar}-\mathrm{H}), 7.32 \sim 7.45(\mathrm{~m}, 3 \mathrm{H}, \mathrm{Ar}-\mathrm{H}), 6.79$ (br s, 1H, Ar-H), 6.16 (d, $J=17.8 \mathrm{~Hz}, 1 \mathrm{H}$, trans-3b-H), $6.15(\mathrm{~d}, J=11.5 \mathrm{~Hz}, 1 \mathrm{H}$, cis-3b-H), 4.69 (d, $J=7.2 \mathrm{~Hz}$,
$1 \mathrm{H}, 17-\mathrm{H}), 4.08$ (q, $J=6.2 \mathrm{~Hz}, 1 \mathrm{H}, 18-\mathrm{H}), 3.79,2.31,2.22$ (each s, each $\left.3 \mathrm{H}, \mathrm{CH}_{3}+\mathrm{OCH}_{3}\right), 3.39 \sim 3.18(\mathrm{~m}, 1 \mathrm{H}, 8 \mathrm{a}-\mathrm{H})$, $3.14 \sim 3.02(\mathrm{~m}, 1 \mathrm{H}, 8 \mathrm{a}-\mathrm{H}), 2.95 \sim 2.84(\mathrm{~m}, 2 \mathrm{H}, 17 \mathrm{a}+$ $17 \mathrm{~b}-\mathrm{H}), 2.77 \sim 2.66(\mathrm{~m}, 2 \mathrm{H}, 17 \mathrm{a}+17 \mathrm{~b}-\mathrm{H}), 2.05$ (d, $J=6.0$ $\left.\mathrm{Hz}, 3 \mathrm{H}, 18-\mathrm{CH}_{3}\right), 1.43$ (t, $\left.J=7.2 \mathrm{~Hz}, 3 \mathrm{H}, 8 \mathrm{a}-\mathrm{CH}_{3}\right), 0.82$ (br $\mathrm{s}, 1 \mathrm{H}, \mathrm{NH}),-1.00$ (br s, $1 \mathrm{H}, \mathrm{NH}) ;{ }^{13} \mathrm{C} \mathrm{NMR}(151 \mathrm{MHz}$, Chloroform- $d$ ) $\delta$ : 173.16, 160.66, 158.68, 157.39, 154.50, $152.21,149.33,148.59,147.71 \sim 147.15(\mathrm{~m}), 142.10$, $142.03,140.36,139.50,139.08,138.93,138.58,136.26$, $134.37,134.28,132.84,132.37,130.66,129.33,129.11$, $128.26,128.23,125.49,123.98,120.27,118.48 \sim 118.12$ (m), 106.41, 106.38, 105.30, 102.92, 93.19, 51.41, 50.42, 46.33, 22.75, 19.06, 17.86, 17.15, 12.41, 11.71, 10.63; EI-MS $m / z$ : $787.5\left(\mathrm{M}+\mathrm{H}^{+}\right)$. Anal. calcd for $\mathrm{C}_{50} \mathrm{H}_{42} \mathrm{~N}_{8} \mathrm{O}_{2}$ : C 76.31, H 5.38, N 14.24; found C 76.51, H 5.49, N 14.43.

12: m.p. $>300{ }^{\circ} \mathrm{C}$; UV-vis $\left(\mathrm{CH}_{2} \mathrm{Cl}_{2}\right) \lambda_{\max }$ (relative intensity): 451 (1.00), 503 (0.10), 582 (0.34), 705 (0.21), $768(0.86) \mathrm{nm} ;{ }^{1} \mathrm{H}$ NMR $\left(400 \mathrm{MHz}, \mathrm{CDCl}_{3}\right) \delta: 10.55$ (br s, $1 \mathrm{H}, 12-\mathrm{NH}), 8.63,8.62,7.82$ (each s, 3H, meso-H), 7.87 (br s, 2H, Ar-H), $7.60 \sim 7.77$ (m, 3H, Ar-H), 7.69 (dd, $J=$ 17.8, $11.5 \mathrm{~Hz}, 1 \mathrm{H}, 3 \mathrm{a}-\mathrm{H}), 7.33 \sim 7.54$ (m, 5H, Ar-H), 6.27 (d, $J=17.8 \mathrm{~Hz}, 1 \mathrm{H}$, trans-3b-H), $6.16(\mathrm{dd}, J=11.5 \mathrm{~Hz}$, $1 \mathrm{H}$, cis-3b-H), 5.27 (d, $J=9.3 \mathrm{~Hz}, 1 \mathrm{H}, 17-\mathrm{H}), 4.09$ (q, $J=$ $6.9 \mathrm{~Hz}, 1 \mathrm{H}, 18-\mathrm{H}$ ), 3.71, 2.81, 2.46 (each s, each $3 \mathrm{H}, \mathrm{CH}_{3}$ $\left.+\mathrm{OCH}_{3}\right), 3.41 \sim 3.28(\mathrm{~m}, 1 \mathrm{H}, 8 \mathrm{a}-\mathrm{H}), 3.25 \sim 3.14(\mathrm{~m}, 1 \mathrm{H}$, $8 \mathrm{a}-\mathrm{H}), 2.92 \sim 2.85(\mathrm{~m}, 1 \mathrm{H}, 17 \mathrm{a}+17 \mathrm{~b}-\mathrm{H}), 2.65 \sim 2.59(\mathrm{~m}$, $1 \mathrm{H}, 17 \mathrm{a}+17 \mathrm{~b}-\mathrm{H}$ ), $2.20 \sim 1.98$ (each m, $2 \mathrm{H}, 17 \mathrm{a}+17 \mathrm{~b}-\mathrm{H}$ ), 1.89 (d, $\left.J=6.2 \mathrm{~Hz}, 3 \mathrm{H}, 18-\mathrm{CH}_{3}\right), 1.45(\mathrm{t}, J=7.5 \mathrm{~Hz}, 3 \mathrm{H}$, $8 \mathrm{a}-\mathrm{CH}_{3}$ ), 0.65 (br s, 1H, NH), 0.80 (br s, 1H, NH); EI-MS $m / z$ : $803.4\left(\mathrm{M}+\mathrm{H}^{+}\right)$. Anal.calcd for $\mathrm{C}_{50} \mathrm{H}_{42} \mathrm{~N}_{8} \mathrm{O}_{3}: \mathrm{C} 74.79$, H 5.27, N 13.96; found C 74.88, H 5.09, N 13.80.

4.9 Synthesis of methyl 12-(2'-amino-4'(5')-benzoylphenyliminomethyl)-12-demethylpyropheophorbide-a (13ab) and methyl 12-(3'(4')-benzoylbenzimidazolyl)12-demethylpyropheophorbide-a (14ab)

According to the method of synthesizing compound 3, chlorins 13ab and 14ab were prepared in yields of $27 \%$ and $43 \%$, respectively, by the treatment of 12 - formyl pyropheophorbide $\mathbf{2 b}$ with 3,4-diaminobenzophe- none for 7 h.

13ab: UV-vis $\left(\mathrm{CH}_{2} \mathrm{Cl}_{2}\right) \lambda_{\max }$ (relative intensity): 439 (1.00), 502 (0.10), 576 (0.22), 634 (0.21), 693 (0.60) nm; ${ }^{1} \mathrm{H}$ NMR (400 MHz, $\left.\mathrm{CDCl}_{3}\right) \delta: 11.93$ (11.81) (s, 12-NH), 9.79 (9.81), 8.82 (8.83) (each s, each $1 \mathrm{H}$, meso-H), 8.30 (8.10) (s, 1H, Ar-H), $7.89 \sim 8.00(\mathrm{~m}, 5 \mathrm{H}$, meso-H+3a-H+ Ar-H), $7.48 \sim 7.79$ (m, 4H, Ar-H), 6.17 (6.20) (each dd, $J=17.9,1.0 \mathrm{~Hz}, 1 \mathrm{H}$, trans-3b-H), 6.10 (6.12) (dd, $J=11.5$, $1.0 \mathrm{~Hz}, 1 \mathrm{H}$, cis-3b-H), 4.90 (4.62) (d, $J=19.6 \mathrm{~Hz}, 1 \mathrm{H}$, $\left.13^{2}-\mathrm{H}\right), 4.83$ (4.53) (d, $\left.J=19.6 \mathrm{~Hz}, 1 \mathrm{H}, 13^{2}-\mathrm{H}\right), 4.17 \sim 4.26$ $(\mathrm{m}, 1 \mathrm{H}, 18-\mathrm{H}), 3.98 \sim 4.08(\mathrm{~m}, 1 \mathrm{H}, 17-\mathrm{H}), 3.69$ (3.68), 3.17 (3.10), 3.06 (3.08) (each s, each $3 \mathrm{H}, \mathrm{OCH}_{3}+\mathrm{CH}_{3}$ ), $3.43 \sim 3.55(\mathrm{~m}, 2 \mathrm{H}, 8 \mathrm{a}-\mathrm{H}), 2.49 \sim 2.34(\mathrm{~m}, 2 \mathrm{H}, 17 \mathrm{a}+$ 17b-H), $2.77 \sim 2.57$ (m, 2H, 17a+17b-H), 1.88 (1.87) (d, each $\left.3 \mathrm{H}, J=7.3 \mathrm{~Hz}, 3 \mathrm{H}, 18-\mathrm{CH}_{3}\right), 1.52$ (1.56) (t, $J=7.4$ $\left.\mathrm{Hz}, 3 \mathrm{H}, 8-\mathrm{CH}_{3}\right), 0.85$ (br s, $\left.1 \mathrm{H}, \mathrm{NH}\right),-0.58(-0.55)$ (br s, $1 \mathrm{H}, \mathrm{NH})$; EI-MS $m / z$ : $757.4\left(\mathrm{M}+\mathrm{H}^{+}\right)$. Anal. calcd for 
$\mathrm{C}_{47} \mathrm{H}_{44} \mathrm{~N}_{6} \mathrm{O}_{4}$ : C 74.58, H 5.86, N 11.10; found $\mathrm{C} 74.41, \mathrm{H}$ 5.79, N 11.18 .

14ab: UV-vis $\left(\mathrm{CH}_{2} \mathrm{Cl}_{2}\right) \lambda_{\max }$ (relative intensity): 441 (1.00), 531 (0.06), 568 (0.12), 643 (0.10), 704 (0.65) nm; ${ }^{1} \mathrm{H}$ NMR (400 MHz, $\left.\mathrm{CDCl}_{3}\right) \delta: 14.53$ (14.60) (s, $1 \mathrm{H}$, 12-NH), 10.62 (10.75), 9.00 (9.01), 8.39 (8.41) (each s, each $1 \mathrm{H}$, meso-H), $7.38 \sim 8.08(\mathrm{~m}, 9 \mathrm{H}, \mathrm{Ar}-\mathrm{H}+3 \mathrm{a}-\mathrm{H}), 6.12$ (6.14) (each d, $J=17.7 \mathrm{~Hz}, 1 \mathrm{H}$, trans-3b-H), 6.00 (6.02) (d, $J=11.5 \mathrm{~Hz}, 1 \mathrm{H}$, cis-3b-H), 5.39 (5.37) (d, $J=19.7 \mathrm{~Hz}$, $\left.1 \mathrm{H}, 13^{2}-\mathrm{H}\right), 5.23$ (5.28) (d, $\left.J=19.7 \mathrm{~Hz}, 1 \mathrm{H}, 13^{2}-\mathrm{H}\right), 4.31 \sim$ $4.38(\mathrm{~m}, 1 \mathrm{H}, 18-\mathrm{H}), 4.16(\mathrm{~d}, J=8.9 \mathrm{~Hz}, 1 \mathrm{H}, 17-\mathrm{H}), 3.47$ (3.48), 3.28, 3.04 (3.06) (each s, each $3 \mathrm{H}, \mathrm{OCH}_{3}+\mathrm{CH}_{3}$ ), $3.62 \sim 3.72(\mathrm{~m}, 2 \mathrm{H}, 8 \mathrm{a}-\mathrm{H}), 2.62 \sim 2.45(\mathrm{~m}, 2 \mathrm{H}, 17 \mathrm{a}+$ 17b-H), $2.27 \sim 2.09$ (m, 2H, 17a+17b-H), 1.79 (1.77) (d, $\left.J=7.6 \mathrm{~Hz}, 3 \mathrm{H}, 18-\mathrm{CH}_{3}\right), 1.64$ (1.69) (t, $J=7.5 \mathrm{~Hz}, 3 \mathrm{H}$, $\left.8-\mathrm{CH}_{3}\right), 0.08$ (br s, 1H, NH), -1.41(1.35) (br s, 1H, NH); EI-MS $m / z$ : $755.2\left(\mathrm{M}+\mathrm{H}^{+}\right)$. Anal. calcd for $\mathrm{C}_{47} \mathrm{H}_{42} \mathrm{~N}_{6} \mathrm{O}_{4}$ : C 74.78, H 5.61, N 11.13; found C 74.84, H 5.69, N 11.29.

Supporting Information ${ }^{1} \mathrm{H}$ NMR and ${ }^{13} \mathrm{C}$ NMR spectra of the new compounds. The Supporting Information is available free of charge via the Internet at http://siocjournal.cn.

\section{References}

[1] (a) Ding Y.; Zhu, W.-H.; Xie, Y. Chem. Rev. 2017, 117, 2203.

(b) Li, M.; Wei, P.; Ishida, M.; Li, X.; Savage, M.; Guo, R. Angew. Chem. Int. Ed. 2016, 55, 3063.

(c) Ding, Y.; Tang, Y.; Zhu, W.; Xie, Y. Chem. Soc. Rev. 2015, 44, 1101 .

(d) Xie, Y.; Tang, Y.; Wu, W.; Wang, Y.; Liu, J.; Li, X. J. Am. Chem. Soc. 2015, 137, 14055.

[2] (a) Stępień, M.; Gońka, E.; Żyła, M.; Sprutta, N. Chem. Rev. 2017, 117,3479

(b) Ono, N.; Yamada, H.; Okujima, T. In Handbook of Porphyrin Science, Eds.: Kadish, K. M.; Smith, K. M.; Guilard, R., Vol. 2. World Scientific Publishing Company, Singapore, 2012, pp. 1-102. (c) Mori, H.; Tanaka, T.; Osuka, A. J. Mater. Chem. C 2013, 1, 2500 .

[3] Senge, M. J. Photochem. Photobiol. 1992, 3.

[4] (a) Zhang, Z.; Jiang, Q,-Y.; Zhang, Q.; Wu, J.; Wang, J.-J. Chin. J. Org. Chem. 2015, 35, 1929 (in Chinese).

(张珠, 姜齐永, 张千, 武进, 王进军, 有机化学, 2015, 35, 1929.) (b) Li, J.-Z.; He, N.-L.; Liu, Y.; Gai, Y.-Y.; Liu. Y.-M.; Yin, J.-G.; Wang, J.-J. Dyes Pigm. 2017, 146, 189.

(c) Wu, X.-R.; Liu, C.; Yang, Z.; Yao, N.-N.; Wang, J.-J. Chin. J. Org. Chem. 2012, 32, 632 (in Chinese).

(邬旭然, 刘超, 杨泽, 姚楠楠, 王进军, 有机化学, 2012, 32, 632.)

(d) Zhang, S.-G.; Li, J.-Z.; Zhang, P.; Qi, C.-X.; Wang, J.-J. Chin. J. Org. Chem. 2015, 35, 1060 (in Chinese).

(张善国, 李家柱, 张朋, 祁彩霞, 王进军, 有机化学, 2015, 35, 1060.)

(e) Zhang, Z.; Xu, X.-S.; Li, Y.-L.; Li, J.-Z.; Wang, J.-J. Chin. J. Org. Chem. 2018, 38, 2993 (in Chinese).
(张珠, 徐希森, 李彦龙, 李家柱, 王进军, 有机化学, 2018, 38, 2993.)

(f) Wang, J.-J.; Li, J.-Z.; Li, Y.-W.; Jakus. J.; Shim, Y. K. J. Porphyrins Phthalocyanines 2010, 14, 860.

[5] (a) Takahashi, T.; Ogasawara, S.; Shinozaki, Y.; Tamiaki, H. Bull. Chem. Soc. Jpn. 2020, 93, 467.

(b) Kozyrev, A. N.; Suresh, V.; Das, S.; Senge, M. O.; Shibata, M.; Doughertya, T. J.; Pandeya, R. K. Tetrahedron 2000, 56, 3353.

(c) Chen, Y.; Sajjad, M.; Wang, Y..; Batt, C.; Nabi, H. A.; Pandey, R. K. ACS Med. Chem. Lett. 2011, 2, 136.

[6] Mysliwiec, D.; Donnio, B.; Chmielewski, P. J.; Heinrich, B.; Stepien, M. J. Am. Chem. Soc. 2012, 134: 4822.

[7] Tokuji, S.; Takahashi, Y.; Shinmori, H.; Shinokubo, H.; Osuka, A. Chem. Commun. 2009, 1028.

[8] Akita, M.; Hiroto, S.; Shinokubo, H. Angew. Chem. Int. Ed. 2012 $51,2894$.

[9] Smith, K. M.; Gogg, D. A.; Simpson, D. J. J. Am. Chem. Soc. 1985 $107,4946$.

[10] Wang, J.-J.; Han, G.-F.; Shim, Y.-K. J. Iran. Chem. Soc. 2011, 8, 965.

[11] (a) Wang, J.-J.; Wang, P.; Li, J.-Z.; Jakus, J.; Shin, Y.-K. Bull. Korean Chem. Soc. 2011, 32, 3473.

(b) Wang, P.; Yang, Z.; Li, J.-Z.; Yao, N.-N.; Wang, J.-J. Chin. J. Org. Chem. 2012, 32, 368 (in Chinese).

(王朋, 杨泽, 李家柱, 姚楠楠, 王进军, 有机化学, 2012, 32, 368.)

(c) Zhang, S.-G. M.S. Thesis, Yantai University, Yantai, 2015 (in Chinese).

(张善国, 硕士论文, 烟台大学, 烟台, 2015.)

(d) Li, J.-Z.; Liu, W.-H.; Li, F.-G.; Wang, J.-J.; Suo, Y.-R.; Liu, Y.-J. Chin.J. Org. Chem. 2007, 27, 1594 (in Chinese).

(李家柱, 刘万卉, 李付国, 王进军, 索有瑞, 刘永军, 有机化学, 2007, 27, 1594.)

(e) liu, R.-R.; Wang, L.-M.; Yin, J.-G.; Wu, J.; Liu, C.; Zhang, P.; Wang, J.-J. Chin. J. Org. Chem. 2012, 32, 318 (in Chinese). (刘舟舟, 王鲁敏, 殷军港, 武进, 刘超, 张朋, 王进军, 有机化 学, 2012, 32, 318.)

[12] Wang, J.-J.; Shim, Y.-K.; Jiang, G.-J.; Imafuku, K. J. Heterocycl. Chem. 2003, 40, 1075 .

[13] Tamiaki, H.; Wada, A.; Matsubara, S. J. Photochem. Photobiol. A: Chem. 2018, 353, 581 .

[14] Matsubara, S.; Shoji, S.; Tamiaki, H. J. Photochem. Photobiol. A: Chem. 2017, 340, 53.

[15] (a) Pandey, S. K.; Zheng, X.; Morgan, J.; Missert, J. R.; Liu, T.-H.; Shibata, M.; Bellnier, D. A.; Oseroff, A. R.; Henderson, B. W.; Dougherty, T. J.; Pandey, R. K. Mol. Pharm. 2007, 4, 448.

(b) Li, J.; He, N.; Liu, Y.; Zhang, Z.; Zhang, X.; Han, X.; Gai, Y.; Liu, Y.; Yin, J.; Wang, J. Dyes Pigments. 2017, 146, 189.

(c) Jiang, Q.-Y.; Zhang, Z.; Liu, Y.; Yao, N.-N.; Wang, J-J. Chin. J. Org. Chem. 2017, 37, 1814 (in Chinese).

(姜齐永, 张珠, 刘洋, 姚楠楠, 王进军, 有机化学, 2017, 37, 1814.)

(d) Duan, S.; Dall'Agnese, C.; Chen, G.; Wang, X.-F.; Tamiaki, H.; Yamamoto, Y.; Ikeuchi, T.; Sasaki, S. ACS Energy Lett. 2018, 3, 1708 .

(e) Wang, J.-J. Chin. J. Org. Chem. 2005, 25, 1353 (in Chinese). (王进军, 有机化学, 2005, 25, 1353.)

[16] Liu, H.-Y.; Zhu, G.-H.; Liu, R.-R.; Jin, Y.-X.; Qi, C,-X.; Wang, J.-J. Chin. J. Org. Chem. 2015, 35, 1320 (in Chinese) (刘红瑶, 朱国华, 刘再冉, 金英学, 祁彩霞, 王进军, 有机化学, 2015, 35, 1320.) 